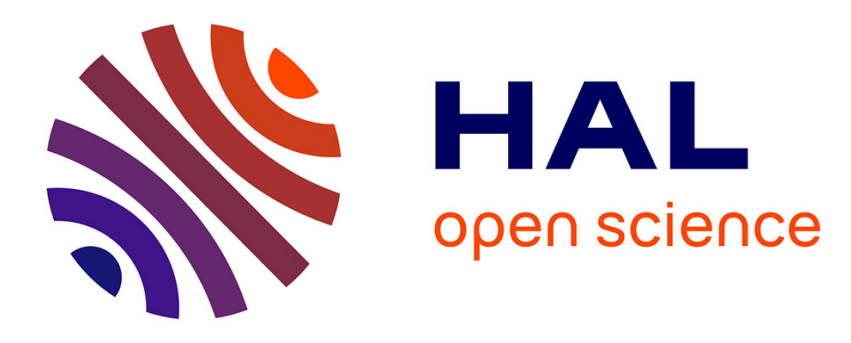

\title{
The Cenozoic evolution of the Roer Valley Rift System integrated at a European scale
}

\author{
Laurent Michon, R. T. van Balen, Olivier Merle, Henk Pagnier
}

\section{To cite this version:}

Laurent Michon, R. T. van Balen, Olivier Merle, Henk Pagnier. The Cenozoic evolution of the Roer Valley Rift System integrated at a European scale. Tectonophysics, 2003, 367, pp.101-126. 10.1016/S0040-1951(03)00132-X . hal-01382032

\section{HAL Id: hal-01382032 \\ https://hal.univ-reunion.fr/hal-01382032}

Submitted on 3 Nov 2016

HAL is a multi-disciplinary open access archive for the deposit and dissemination of scientific research documents, whether they are published or not. The documents may come from teaching and research institutions in France or abroad, or from public or private research centers.
L'archive ouverte pluridisciplinaire HAL, est destinée au dépôt et à la diffusion de documents scientifiques de niveau recherche, publiés ou non, émanant des établissements d'enseignement et de recherche français ou étrangers, des laboratoires publics ou privés. 


\title{
The Cenozoic evolution of the Roer Valley Rift System integrated at a European scale
}

\author{
Laurent Michon $^{\mathrm{a}, *}$, Ronald T. Van Balen ${ }^{\mathrm{b}}$, Olivier Merle ${ }^{\mathrm{c}}$, Henk Pagnier ${ }^{\mathrm{a}}$ \\ ${ }^{a}$ Department of Geo-Energy, TNO-NITG, PO Box 80015, 3508 TA Utrecht, The Netherlands \\ ${ }^{\mathrm{b}}$ Department of Quaternary Geology, Vrije Universiteit Amsterdam, De Boelelaan 1085, 1081 HV Amsterdam, The Netherlands \\ ${ }^{\mathrm{c}}$ Laboratoire Magmas et Volcans, OPGC, Université Blaise Pascal, 5 rue Kessler, 63038 Clermont-Ferrand, France
}

\begin{abstract}
The Roer Valley Rift System (RVRS) is located between the West European rift and the North Sea rift system. During the Cenozoic, the RVRS was characterized by several periods of subsidence and inversion, which are linked to the evolution of the adjacent rift systems. Combination of subsidence analysis and results from the analysis of thickness distributions and fault systems allows the determination of the Cenozoic evolution and quantification of the subsidence. During the Early Paleocene, the RVRS was inverted (Laramide phase). The backstripping method shows that the RVRS was subsequently mainly affected by two periods of subsidence, during the Late Paleocene and the Oligocene-Quaternary time intervals, separated by an inversion phase during the Late Eocene. During the Oligocene and Miocene periods, the thickness of the sediments and the distribution of the active faults reveal a radical rotation of the direction of extension by about $70-80^{\circ}$ (counter clockwise). Integration of these results at a European scale indicates that the Late Paleocene subsidence was related to the evolution of the North Sea basins, whereas the Oligocene-Quaternary subsidence is connected to the West European rift evolution. The distribution of the inverted provinces also shows that the Early Paleocene inversion (Laramide phase) has affected the whole European crust, whereas the Late Eocene inversion was restricted to the southern North Sea basins and the Channel area. Finally, comparison of these deformations in the European crust with the evolution of the Alpine chain suggests that the formation of the Alps has controlled the evolution of the European crust since the beginning of the Cenozoic.
\end{abstract}

Keywords: Roer Valley Rift System; Western Europe; Rift; Cenozoic; Subsidence; Inversion

\section{Introduction}

North of the Upper Rhine Graben (URG), the Roer Valley Rift System (RVRS) corresponds to the northern segment of the European Cenozoic rift system described by Ziegler (1988) (Fig. 1a). The Cenozoic RVRS developed upon pre-existing basins of Carbon-

* Corresponding author. Fax: +31-30-256-46-05.

E-mail address: 1.michon@nitg.tno.nl (L. Michon). iferous (Campine foreland basin) and Mesozoic (rift) age. It is structurally closely related to the Mesozoic basin. During the Mesozoic, the area was characterized by several periods of subsidence and inversion, which have reactivated the Variscan structural trends (Ziegler, 1990; Zijerveld et al., 1992; Winstanley, 1993; Geluk et al., 1994). During the Cenozoic, the RVRS was affected by two periods of inversion named the Laramide phase (Earliest Tertiary) and the Pyrenean phase (Late Eocene-Early Oligocene) 


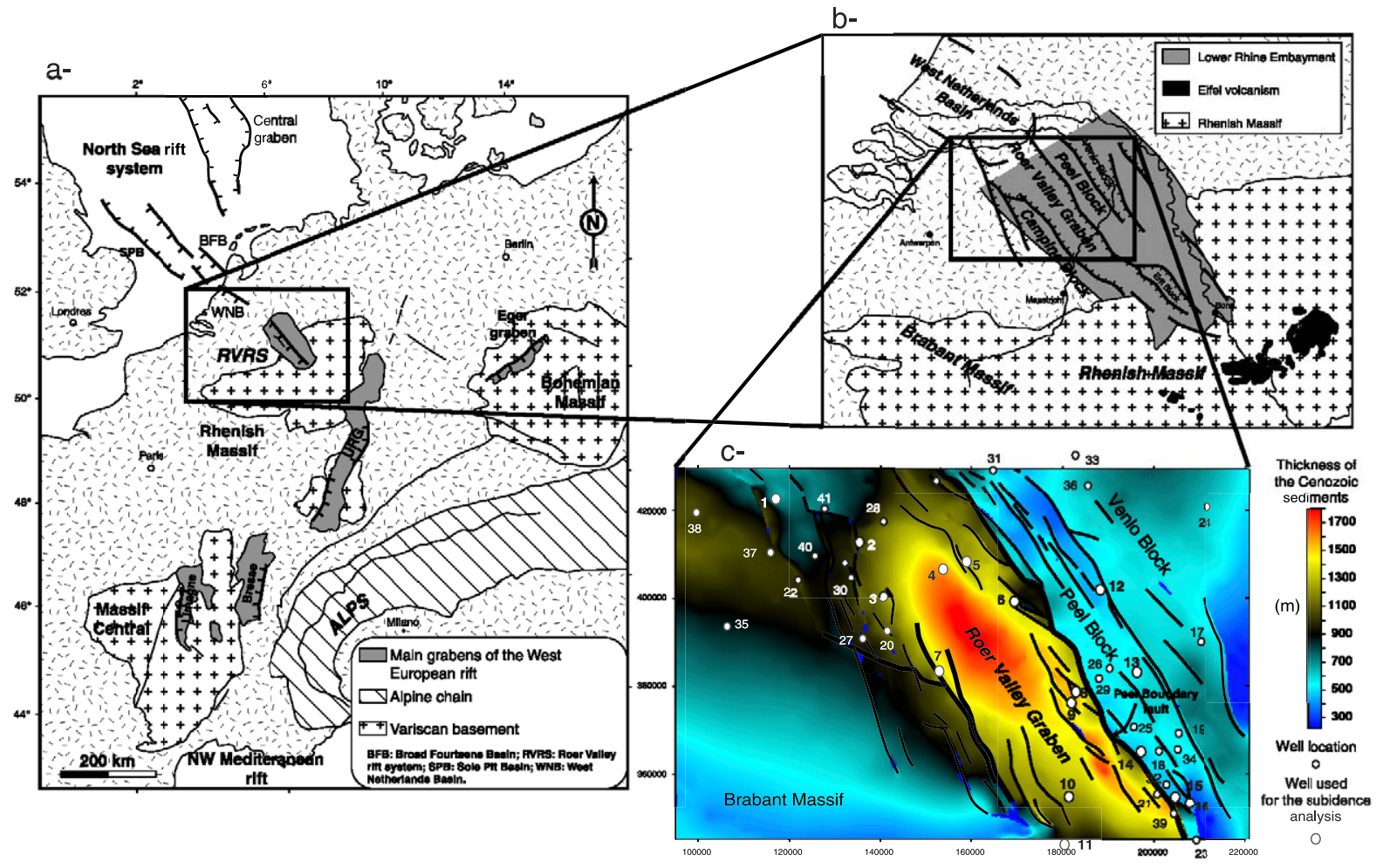

Fig. 1. (a) Location map of the Roer Valley rift system (RVRS) in northwestern Europe. (b) Tectonic features of the Lower Rhine Embayment and the RVRS. The insert corresponds to the studied area covered by the seismic interpretation. (c) Location map of the deep wells used for the subsidence analysis and the additional wells. The background image is a seismic interpretation of the thickness of the Tertiary sediments. See Appendix A for the name of the wells.

and by continuous subsidence since the beginning of the Oligocene (Geluk et al., 1994; Houtgast and Van Balen, 2000). Preserved Late Oligocene-Early Miocene marine sediments on the Rhenish Massif demonstrate that the Roer Valley Graben (RVG) was connected to the URG (Murawski et al., 1983; Sissingh, 1998), indicating a common evolution during at least this period. A close relationship between these two grabens is also suggested by the distribution of the earthquake focal mechanisms in the northern part of the URG and the RVG which indicate a present-day $\mathrm{NE}-\mathrm{SW}$ extension in both areas (Plenefisch and Bonjer, 1997).

Structurally, the RVRS is part of the Lower Rhine Embayment and consists from southwest to northeast of the Campine Block, the RVG and the Peel Block (Fig. 1b). The graben, which is $20 \mathrm{~km}$ wide and 130 $\mathrm{km}$ long, has been controlled by the multi-stage activity of several major fault zones (Peel Boundary fault zone, Veldhoven fault zone, Rijen fault zone and Feldbiss fault zone) of Mesozoic or (probably) older age. The different activity of these fault zones has induced the formation of a present-day asymmetric structure with the main offsets located along the Peel Boundary fault zone.

The aim of this paper is to determine precisely the Cenozoic evolution of the RVG and the paleo-stress fields that have caused the reactivation of this structure. This study is based (1) on subsidence analysis inferred from deep wells situated in the graben and on its shoulders and (2) on inspection of maps (depth of base Late Cretaceous, base Tertiary and base Miocene sedimentation) resulting from mainly $2 \mathrm{D}$ and $3 \mathrm{D}$ seismic interpretation. The combination of these two approaches allows the quantification of the tectonic subsidence and determination of fault activity during the different Cenozoic time periods. For each period of sedimentation (or erosion), the characteristics of 
subsidence and the paleo-stress field can be deduced. Nevertheless, the density of seismic lines is not high enough to allow observation of small-scale tectonic structures (e.g., en echelon folds), which could provide additional information on the paleo-stress field. Comparison with the Cenozoic evolution of the surrounding rift systems (i.e., European Cenozoic rift system and the southern North Sea rift) allows to integrate the RVG evolution at a European scale. Our results are partly in agreement with the paleo-stress field orientations inferred from microtectonic data (e.g., Villemin and Bergerat, 1987). We discuss in a later section the potential origin of the differences found for the Late Eocene and Oligocene periods.

Subsidence analysis determines the tectonic subsidence apart from the total subsidence by applying the backstripping method (e.g., Van Hinte, 1978; Zijerveld et al., 1992). The other components of evolution are, for example, isostasy and compaction. The subsidence analysis is based on the analysis of 16 deep wells distributed in the graben and on its shoulders (Fig. 1c and Appendix A). Six of these wells have already been studied by Zijerveld et al. (1992). However, the large time frame studied in their work $(250 \mathrm{Ma})$ does not provide detailed information concerning the Cenozoic evolution of the RVRS. In this paper, the tectonic subsidence of the Cenozoic time interval is studied in more detail and it is supplemented by the results for 10 additional wells, in order to determine the subsidence distribution and to assess the development of depocentres through time.

Although subsidence analysis provides fundamental information concerning the quantification of tectonic subsidence, the spatial distribution is poorly constrained. To close this gap of information, we have studied 25 additional deep wells for which the stratigraphic data are not detailed enough for backstripping analyses, but can still help to define the dynamics of each block and the tectonic activity for each period (Late Cretaceous-Early Paleocene, Late Paleocene, Early Oligocene, Late Oligocene and Miocene-Quaternary). Thus, altogether 41 wells are used to constrain the spatio-temporal distribution of the subsidence during the Cenozoic.

The Netherlands Institute of Applied Geoscience TNO-National Geological Survey has recently published the map sheets XIII and XIV of the Geological Atlas of the Subsurface of the Netherlands (NITG-
TNO, 2001). These maps, which represent the depth and the thickness of several horizons, have been inferred from 2D and 3D seismic interpretation. For the Cenozoic period, maps corresponding to the "base Tertiary" (base Late Paleocene) and base Miocene (Breda Formation) horizons were created, allowing the thicknesses of the Paleogene and Neogene sediments to be determined. An additional map corresponding to the thickness of the Chalk deposits (Late Cretaceous-Early Paleocene) has been used in the present study in order to determine the deformation caused by the Laramide phase in the beginning of the Cenozoic.

\section{Geological setting and fault system}

The RVRS is the southwestern part of the Lower Rhine Embayment. Located in Belgium, Germany and the Netherlands, it consists of, from southwest to northeast, the Campine Block, the Roer Valley Graben and the Peel Block (the Campine and Peel Blocks corresponding to the RVG shoulders). The southeastern end of the RVRS is formed by the Erft Block, which is not in the prolongation of the RVG but shifted towards the northeast (Fig. 1b). In the northwest, the West Netherlands Basin is the continuation of the Mesozoic RVRS. The transition area between these two Mesozoic structures is characterized by a sedimentation and a fault pattern which has similarities with both grabens.

During the Mesozoic, the RVRS was affected by several periods of subsidence. Between the Late Permian and Early Triassic, the RVRS was characterized by thermal subsidence and minor fault activity as attested by a thick homogeneous sedimentation in the RVG, on the Peel Block and on the Campine Block (Zijerveld et al., 1992; Winstanley, 1993). Contrary to this period, the Late Jurassic-Early Cretaceous evolution corresponds to a major rifting event during which the RVG has strongly subsided, and the Peel and Campine Blocks were uplifted (Zijerveld et al., 1992; Geluk et al., 1994). Subsidence was controlled by the reactivation of the main Variscan faults in a normal faulting mode (the Peel Boundary fault zone, the Rijen fault zone and the Veldhoven fault zone). Most of the sediments deposited during this period have been later eroded during the first Late Creta- 
ceous inversion event (Winstanley, 1993). A second phase of inversion, characterized by two pulses, occurred during the latest Late Cretaceous and the earliest Tertiary, contemporaneous with a general transgression. In the RVRS, the erosion or the lack of sedimentation of Chalk (Cenomanian-Danian) deposits renders the distinction between these two pulses of inversion impossible. The resulting sedimentation is characterized by a very thin sediment deposit in the RVG and an important subsidence of the Peel Block (Gras and Geluk, 1999).

At a regional scale, the RVRS is characterized by a NW-SE orientation which is regarded as parallel to the main Variscan inheritance (e.g., Ziegler, 1990; Geluk et al., 1994). This general trend can be specified by the analysis of detailed fault maps for the Triassic, Late
Cretaceous and Miocene periods which provide essential information concerning (1) the role of the inheritance in the RVRS and (2) the distinction of two different structural domains. Fault distribution determined from the Triassic, Late Cretaceous and Miocene active faults reveals that most of the Triassic structures were reactivated during the Late Cretaceous and Miocene evolutions, whatever the type of deformation (inversion, thermal subsidence and rifting) (Fig. 2). Comparison of the rose diagrams of fault strikes inferred for different time periods shows only minor differences. Their similarity can be explained by reactivation of the inherited fault orientations, despite different stress fields responsible for the faulting activity.

The fault orientations also indicate the existence of two distinct structural domains separated by the cen-

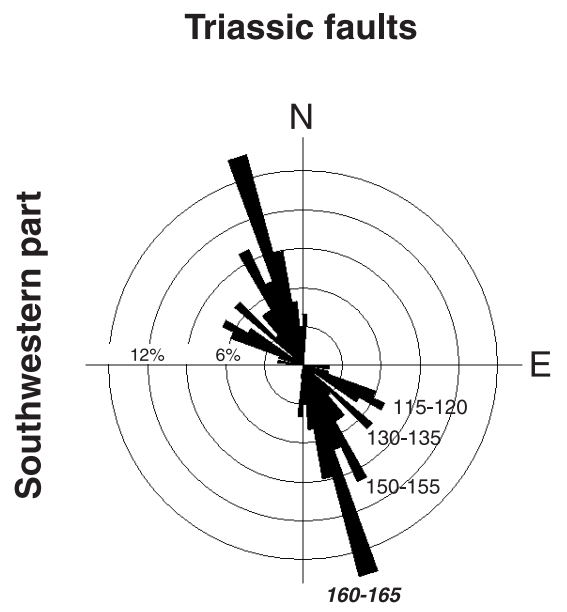

\section{Late Cretaceous faults}

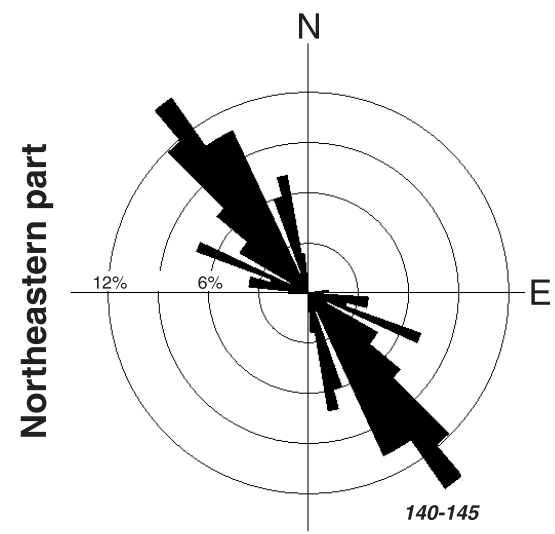

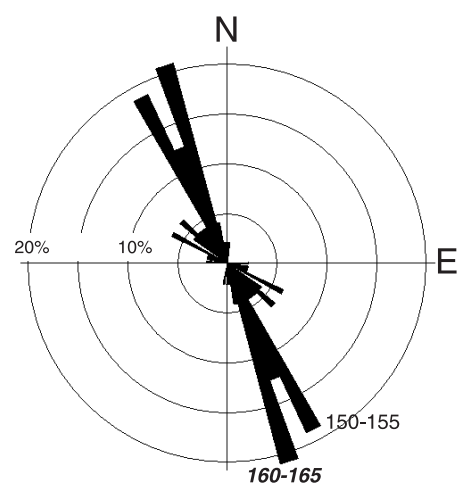

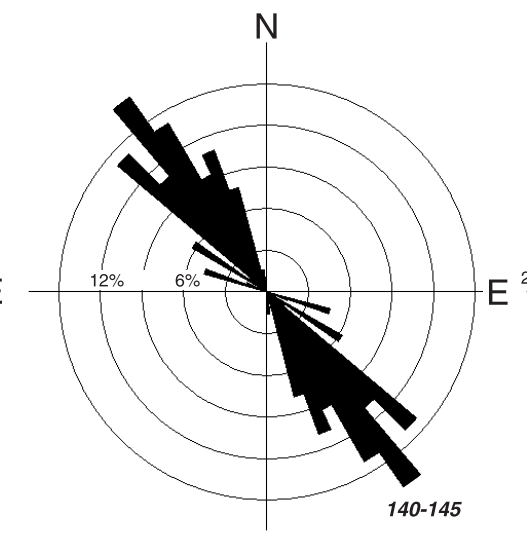

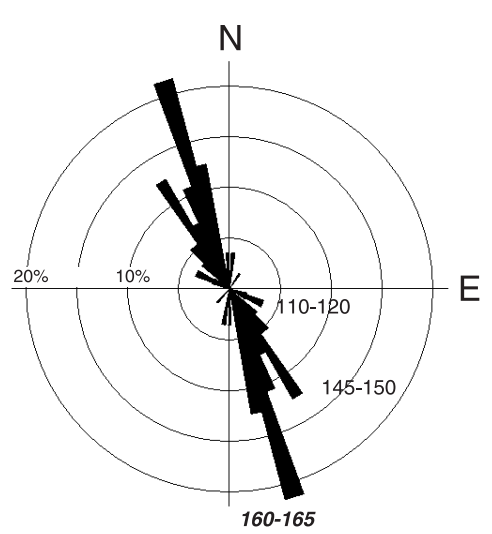

Miocene faults

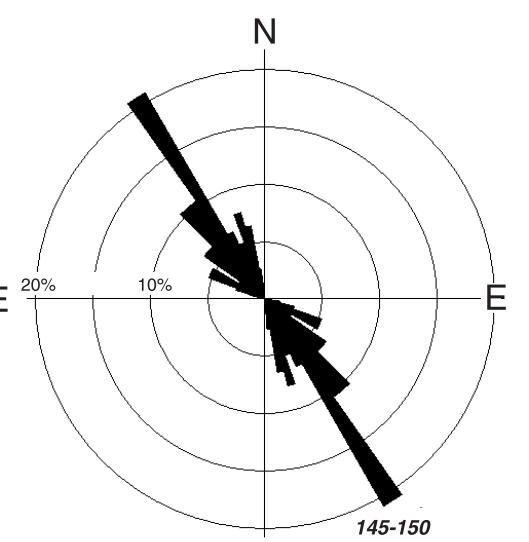

Fig. 2. Distribution of the active faults during the Triassic, Late Cretaceous and Miocene periods. The rose diagram representation is based on fault frequency and allows determination of the most important fault trends. See text for explanation. 
tral axis of the RVG. The southwestern border is characterized by a main structural orientation of N160-165, whereas in the northeastern border (i.e., the Peel Boundary fault zone and the Peel Block) the N135-145 orientation widely prevails (Fig. 2). To the west, the West Netherlands Basin (Racero-Baena and Drake, 1996) is characterized by a similar fault orientation style as the southwestern part of the RVRS, and the Noord-Holland Platform has similar fault orientations as the northeastern part of the RVRS (Fig. 3). Thus, the boundary between these two fault orientation domains continues along the Zandvoort Ridge, the IJmuiden High and the Indefatigable Fault Zone into the Southern North Sea basin, and seems to represent a fundamental fault zone separating two crustal domains. At the RVRS scale, the development of the two different fault trends cannot be explained by different stress fields but rather by different structural orientations in the basement, which have been inherited from at least the Variscan evolution (the age of the original orientation being poorly constrained).

From this complex structural framework, the different stress fields related to the Cenozoic periods have induced the reactivation of specific fault orientations according to the direction of compression or extension. The analysis of the active faults and their displacement mode during each Cenozoic period then allows determination of the paleo-stress fields.

\section{Subsidence analysis}

Subsidence analysis requires specification of the thickness, the age, the lithology, the porosity/depth curve and the depositional water depth for each unit.

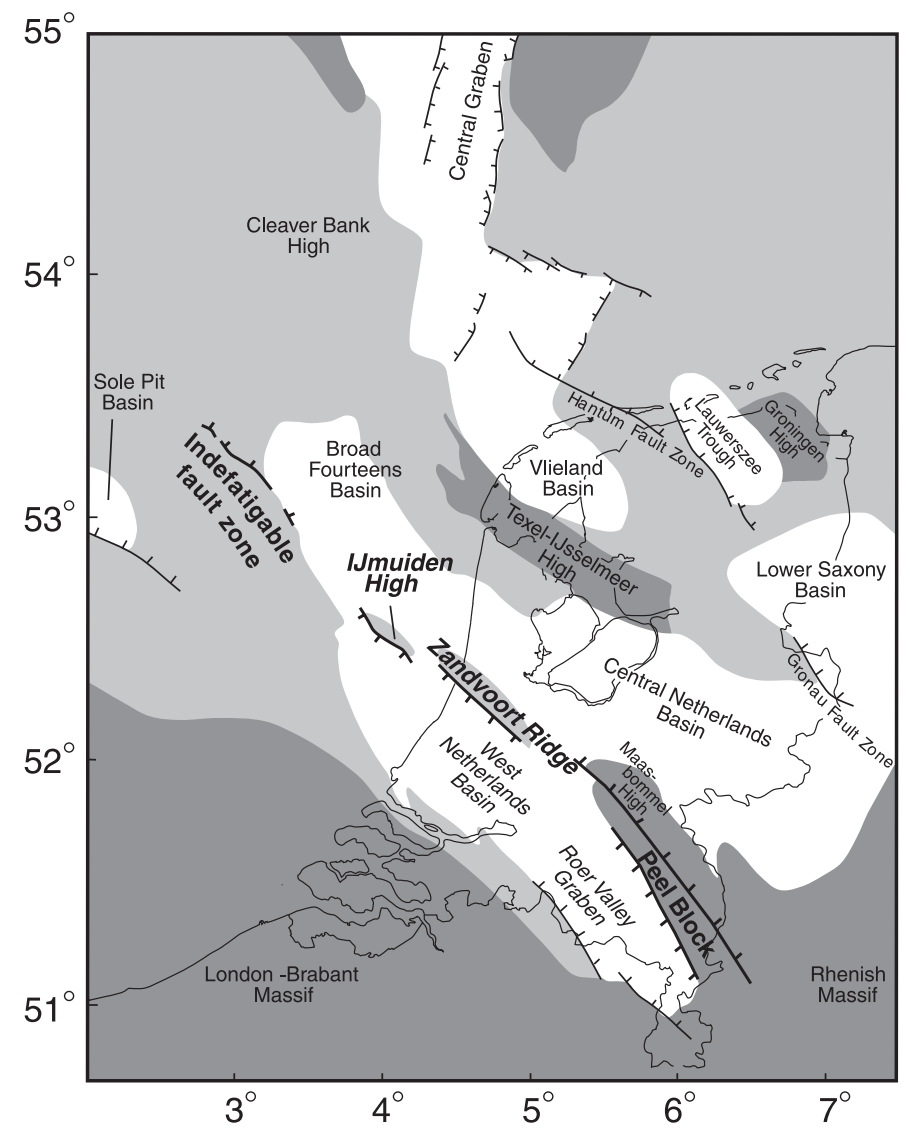

Fig. 3. Simplified structural map of the southern part of the North Sea rift system (after Van Balen et al., 2002). 
In the RVRS, the stratigraphy has been derived from the Stratigraphic Nomenclature of the Netherlands (Nederlandse Aardolie Maatschappij BV and Rijks Geologische Dienst, 1980). We have used standard exponential curves for the porosity-depth relationship corrections taking into account the different lithologies for each wells (e.g., Sclater and Christie, 1980). Paleobathymetry may have a strong influence on the backstripping results. Nevertheless, the RVRS was located on the peripheral margin of the North Sea basin and the paleogeographic interpretations suggest that paleobathymetry never exceeded $50-100 \mathrm{~m}$ (Zagwijn, 1989). Geohistory evolutions determined for different paleobathymetric values reveal that pale- obathymetric variations do not significantly influence the calculated tectonic subsidence $(<10 \%)$. The subsidence analysis thus allows quantification of the tectonic subsidence and the tectonic subsidence rates (TSR) for each period of sedimentation.

Subsidence analysis has been carried out for 16 wells located in the Roer Valley Graben and the Peel Block (Fig. 1c). Calculated tectonic subsidence curves show a Cenozoic evolution marked by two periods of subsidence (Late Paleocene and Oligocene-Quaternary) separated by a hiatus during the Eocene time, resulting from a period of erosion during the Late Eocene (Fig. 4). This Late Eocene event was characterized by an uplift which cannot be quantified with

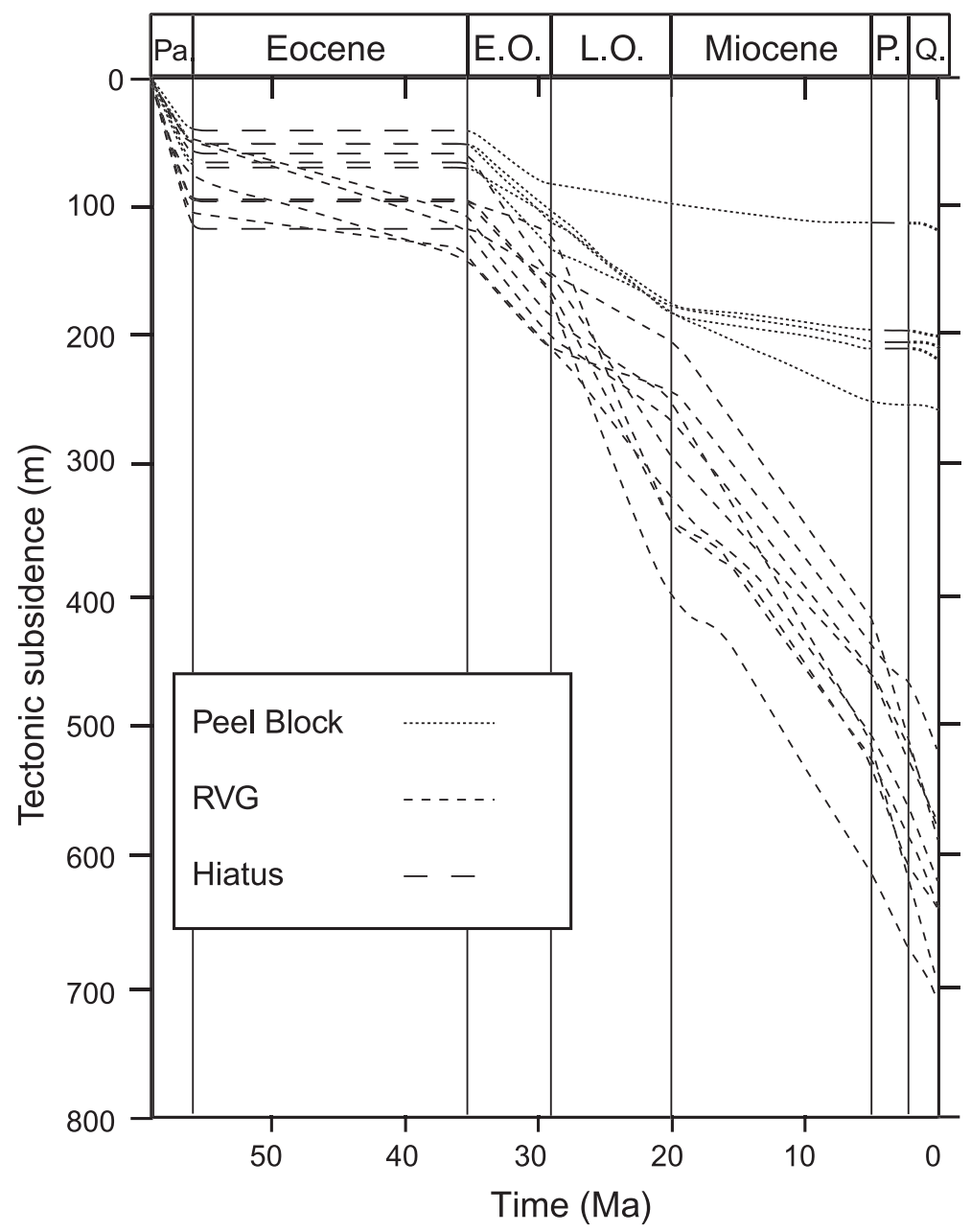

Fig. 4. Calculated tectonic subsidence for wells located in the Roer Valley Graben and the Peel Block. The Late Paleocene and OligoceneQuaternary periods of subsidence are separated by an inversion phase, which is related to the Pyrenean phase during the Late Eocene. 
the available data. Models from apatite-fission track analyses indicate that the uplift in the western part of the RVRS varies between 200 and $600 \mathrm{~m}$. (Van Balen et al., 2002). A second minor hiatus is visible for four wells located on the Peel Block during the start of the Pliocene. Although this hiatus could be interpreted in terms of tectonic inversion (uplift and erosion), it can be considered as the result of a lack of sedimentation related to the Late Miocene marine regression.

The first phase of subsidence (Late Paleocene) was characterized by the widespread sedimentation of the Landen Formation in the RVG and on the Peel Block (see below). For this period, tectonic subsidence rates indicate a different evolution between the southeastern part of the RVG, and the Peel Block and the northwestern part of the RVG. From southeast to northwest, the tectonic subsidence rates in the RVG decrease from $38-47$ to $20-22 \mathrm{~mm} / \mathrm{ky}$. This feature could suggest a tectonic activity mainly concentrated in the southeastern part of the graben. However, it has been shown that the West Netherlands Basin, which corresponds to the northwest continuation of the RVG, was strongly inverted during the early Tertiary phase creating an important relief (Van Balen et al., 2000). The persistence of this relief during the first stage of the Late Paleocene evolution may explain the weak thickness of the Landen formation in the northwestern part of the RVG. In that case, the TSR low values in the northwestern part likely represent an underestimation of the real tectonic subsidence. In contrast, the difference between the tectonic subsidence rates inferred from the wells located on the southeastern part of the Peel Block (21-25 mm/ky) and those located in the graben $(38-47 \mathrm{~mm} / \mathrm{ky})$ clearly suggests a tectonic activity with a fault-controlled tectonic subsidence mainly restricted to the graben.

The second period of subsidence began in the Early Oligocene and is still active during the Quaternary. After the Late Eocene inversion, the RVG and the Peel Block started to subside with similar tectonic subsidence rates $(18-19 \mathrm{~mm} / \mathrm{ky})$, inducing the deposition of the Rupel formation. This common evolution stopped at the beginning of the Late Oligocene, when the tectonic subsidence decreased in the northwestern part of the RVG and the Peel Block (TSR around 10 $\mathrm{mm} / \mathrm{ky}$ ), whereas it strongly accelerated in the southeastern part of the graben (TSR between 20 and 34 $\mathrm{mm} / \mathrm{ky}$ ). The Late Oligocene period was then characterized by a concentration of the deformation mainly located in the northeastern side of the southeastern part of the RVG, where the maximum TSR values are recorded. After the regressive phase at the Oligocene-Miocene transition, the evolution of the northwestern and the southeastern parts became similar with a constant TSR around $19 \mathrm{~mm} / \mathrm{ky}$. This Miocene

a) NW SE

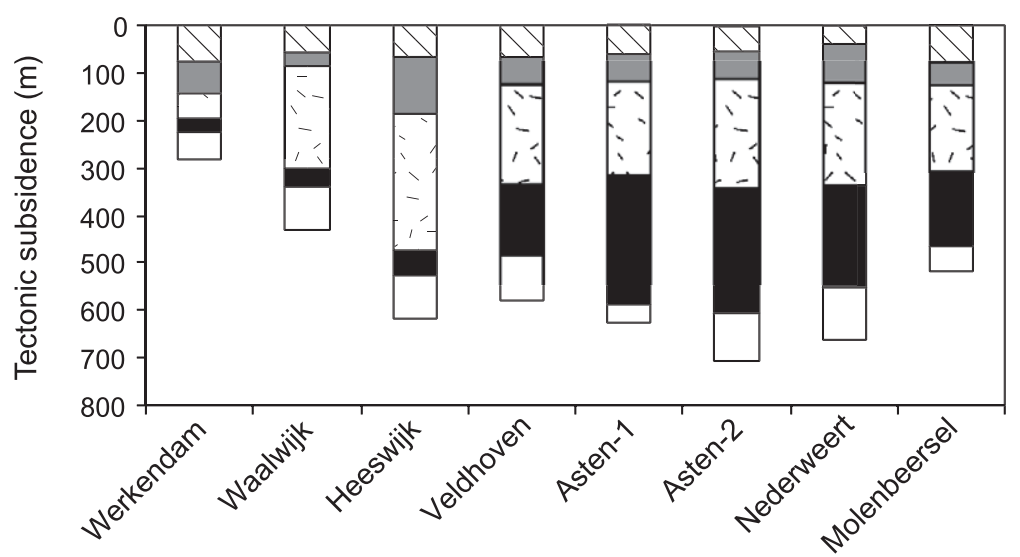

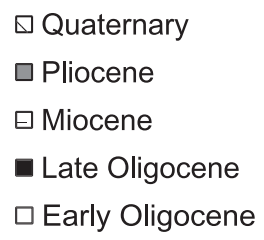

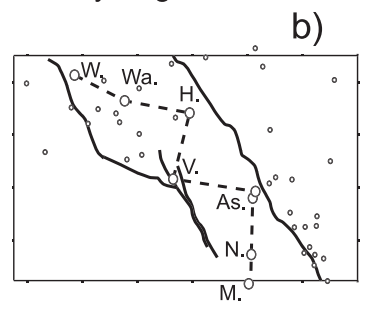

Fig. 5. (a) NW-SE cross section established from eight wells located into the RVG. The development of the Late Oligocene and the MioceneQuaternary depocentres is suggested by the amount of tectonic subsidence along the cross section. (b) Location of the wells used for the cross section. As.: Asten-1 and Asten-2; H.: Heeswijk; M.: Molenbeersel; N.: Nederweert; V.: Veldhoven; Wa.: Waalwijk; W.: Werkendam. 
subsidence was also characterized by the development of a large depocentre in the northwestern part, indicating a northwestward migration of the depocentre between the Late Oligocene and the Miocene (Fig. 5). On the Peel Block, the tectonic subsidence decreases drastically (TSR $<5 \mathrm{~mm} / \mathrm{ky}$ ) suggesting a change in the general evolution of the RVRS with a subsidence restricted to the graben. As it has been already observed (Zijerveld et al., 1992), tectonic subsidence curves reveal an increase of the TSR in the RVG $(+40 \%)$ at the Miocene-Pliocene transition. Thus, since the Pliocene, the subsidence led to the deposition of a 300-400 m thick Plio-Quaternary sedimentation outside the depocentre and more than $500 \mathrm{~m}$ of sediments within the depocentre.

During the Quaternary, the subsidence rate has rapidly changed (Houtgast and Van Balen, 2000) and the subsidence rates determined for this period are between three and four times higher than the TSR deduced for the Plio-Quaternary evolution. One explanation could be that the TSR inferred for geological times (i.e., several m.y.) correspond to an average of the real tectonic subsidence which is probably characterized by short periods of strong subsidence and periods of quiescence. An alternative explanation could be found in the comparison of the amount of tectonic and total subsidence during a rifting event. Assuming that the accommodation space related to the extension was continuously filled by sediments in the RVRS, the comparison of the tectonic subsidence and the thickness of the sediments (i.e., total subsidence) inferred for the northwestern and southeastern parts of the RVG shows a timedependent increasing difference between the tectonic and total subsidence (Fig. 6). The resulting total subsidence rates deduced for the Quaternary are between three and four times higher than the TSR. In consequence, the rapid subsidence of the RVG (88 $\mathrm{mm} / \mathrm{ky}$ ) determined by Houtgast and Van Balen (2000) could be explained by $25 \%$ of tectonic subsidence and $75 \%$ of compaction and isostatic process. For example, delayed compaction of Miocene clays due to slow dewatering could contribute to Quaternary subsidence (Houtgast and Van Balen, 2000). The general trend of tectonic subsidence during Quaternary is characterized by a gradual decrease and a sudden increase during the last $250 \mathrm{ky}$.

\section{Plan view tectonic evolution}

In this section, we combine information provided by the thickness maps for the Late Cretaceous-Early Paleocene, Paleogene and Neogene periods, with the thickness of the sediments observed in 41 wells at different periods (Late Cretaceous-Early Paleocene, Late Paleocene, Eocene, Early Oligocene, Late Oligocene and Miocene-Quaternary). This approach allows us to determine for each period the fault activity and to characterize the distribution of the vertical displacements (i.e., uplift or subsidence). Additional inspection of seismic lines crossing the main border faults reveals that the amount of shortening and extension never exceeded 1-2 km for each period.

For the Late Cretaceous-Early Paleocene period, it is generally assumed that the RVG was affected by compression related to the Late Cretaceous and early
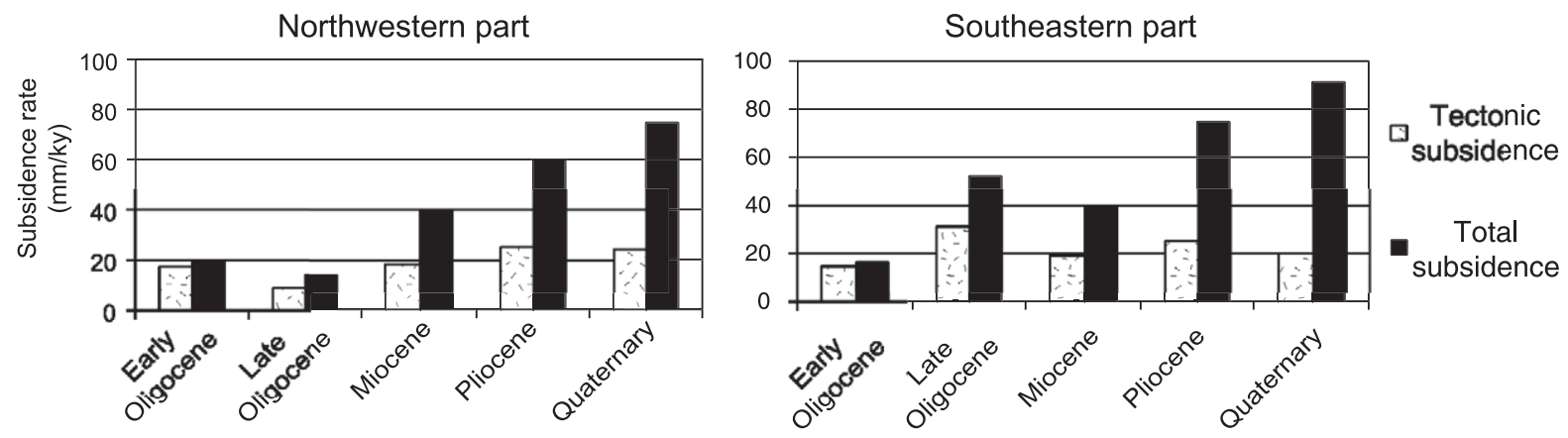

Fig. 6. Comparison of the total subsidence rate and tectonic subsidence rate for the northwestern and southeastern parts of the RVG. See text for explanation. 
Tertiary phases which have induced graben inversion and reactivation of Mesozoic normal faults in a reverse faulting mode (e.g., Ziegler, 1988; Geluk et al., 1994). The distribution of the Late Cretaceous Chalk formation confirms this evolution and clearly shows contrasted thicknesses with a minor thickness of sediments in the RVG and a strong subsidence on its shoulders (Figs. 7a and 8). The uplift is restricted to the graben and has been controlled by the main border faults as it is shown by seismic (Fig. 8). It is noteworthy that these faults present two oblique orientations (WNW-ESE and NW-SE) that are hardly consistent with a compression perpendicular to the graben. Despite the lack of evidence for important strike slip displacement along the NW-SE trending faults, we interpret the Late Cretaceous-Early Paleocene final geometry as the result of a transpressional context with the greatest principal horizontal stress $\left(\sigma_{1}\right)$ between NE-SW and N-S, comparable to the nearby West Netherlands Basin (Racero-Baena and Drake, 1996; Van Balen et al., 2000).

Subsidence analysis for the Late Paleocene period suggests (1) a global subsidence in the studied area (RVG, Peel Block and Venlo Block) (Fig. 7b) and (2) a small fault activity between the Peel Block and the RVG (i.e., the Peel Boundary fault zone). Quantification of the tectonic subsidence provides an estimate for minor vertical displacements along the Peel Boundary fault zone ranging between 50 and $70 \mathrm{~m}$ during this period. It is unlikely that the Late Paleocene subsidence of the Lower Rhine Embayment has resulted from a rifting event generated by far field stresses, because during a rifting process subsidence is generally controlled by a substantial fault activity and is restricted to a graben area. In contrast, it has been proposed that the elastic response of the lithosphere after a period of compression is able to induce subsidence of the inverted area (de Lugt et al., 2003). Then, the slight subsidence $(<100 \mathrm{~m})$ developed after a main compressive phase might result from a stress relaxation and a lithospheric sagging.

Most of the information concerning the Eocene evolution has been partially destroyed by a strong erosion event during the Late Eocene. This erosion phase is related to the uplift of the whole area during the Pyrenean phase (Ziegler, 1988; Geluk et al., 1994). Well data indicate a progressive decrease of the thickness of the Dongen formation (Eocene) towards the east (Fig. 7c). This thinning could result from (1) a less active subsidence in the eastern part of the RVRS and/or (2) a doming of the central part of the Lower Rhine Embayment (i.e., eastern part of the RVRS).

The Early Oligocene marked the onset of the rifting phase in the RVRS. The thickness of the sediments combined with subsidence analysis indicates that the Early Oligocene was affected by a general subsidence with a maximum of vertical displacement in the central part of the Lower Rhine Embayment (Fig. 7d). Similar sediment thicknesses on the Peel Block and the RVG suggest a minor or no fault activity of the Peel Boundary fault zone during this period. In consequence, the origin of Lower Rhine Embayment subsidence is uncertain. Similarly to the Late Paleocene evolution, the Early Oligocene subsidence could result form the elastic response of the lithosphere after the Late Eocene doming. An alternative and additional explanation could be that a slight extension phase has affected the Lower Rhine Embayment during this period.

During the Late Oligocene period, the tectonic subsidence increased in the southeastern part of the RVG with the development of narrow depocentres close to the Peel Boundary fault zone, whereas it decreased in the northwestern half of the RVG and the Peel Block. Well data reveal that the Peel Boundary fault zone was active in its southeastern part only, with vertical offsets ranging between 250 and $300 \mathrm{~m}$. Secondary fault activity along the Peel Boundary fault zone antithetic faults has also controlled the development of the depocentres (Fig. 7e). Such an evolution demonstrates a concentration of the deformation with a significant fault activity bounding the graben. The fault orientation, with a maximum trend around $\mathrm{N} 140-145$ and a secondary trend at N130, suggests again that the inherited structure were reactivated

Fig. 7. Cenozoic evolution of the RVRS. (a) Early Paleocene inversion. (b) Late Paleocene subsidence. (c) Late Eocene doming. (d) Early Oligocene subsidence. (e) Late Oligocene concentrated subsidence due to WNW-ESE rifting. (f) Miocene-Quaternary rifting resulting from a NE-SW extension. For the Late Paleocene, Late Eocene, Early Oligocene and Late Oligocene periods, the background image corresponds to the thickness of the Paleogene sedimentation. The thickness information for each period is provided by the well data. 


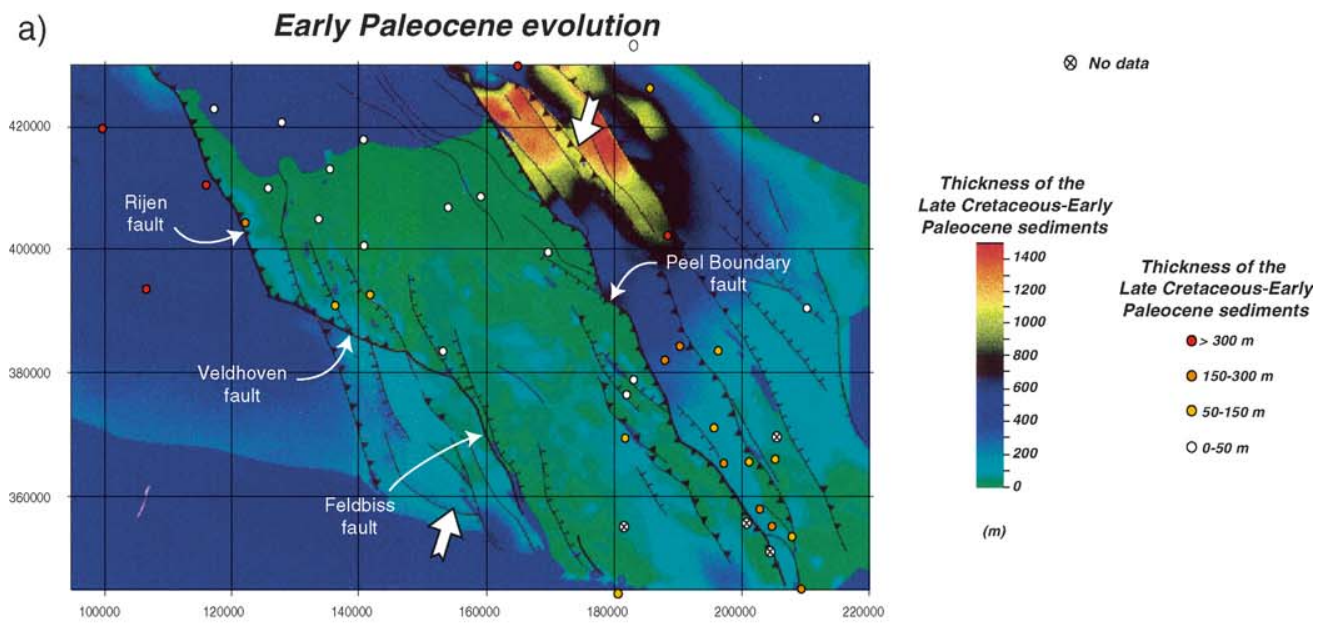

b)

Late Paleocene evolution

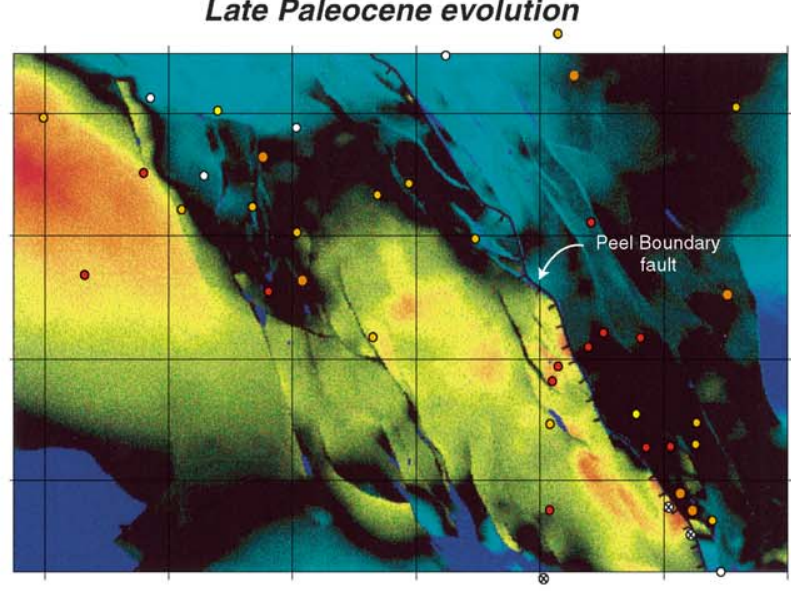

Thickness of the Late Paleocene sediments

o> $100 \mathrm{~m}$

- 75-100 m

$050.75 \mathrm{~m}$

O $25-50 \mathrm{~m}$

$00.25 \mathrm{~m}$

c)

Late Eocene evolution

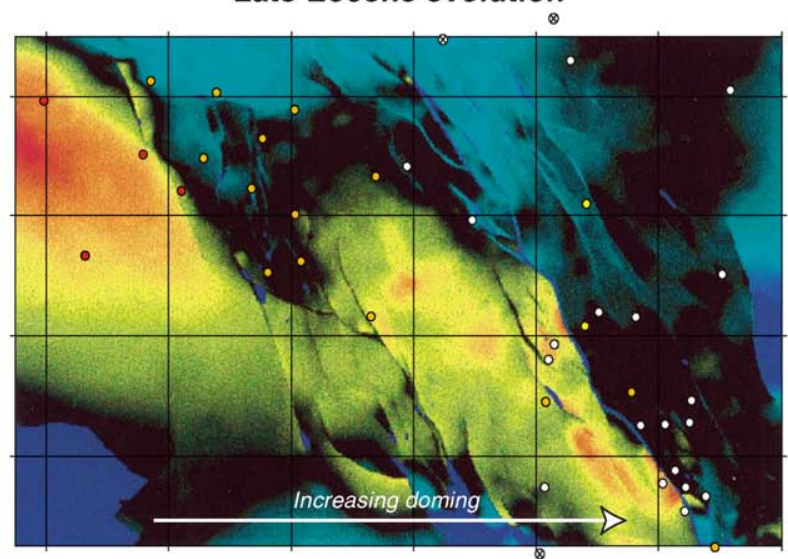

Thickness of the Paleogene sediments 800
-700
-600
-500
-400
-300
-200
-100
0

(m)

Thickness of the Eocene sediments

0>300 m

- $150-300 \mathrm{~m}$

$050.150 \mathrm{~m}$

$0.50 \mathrm{~m}$

$00 \mathrm{~m}$ 
d)

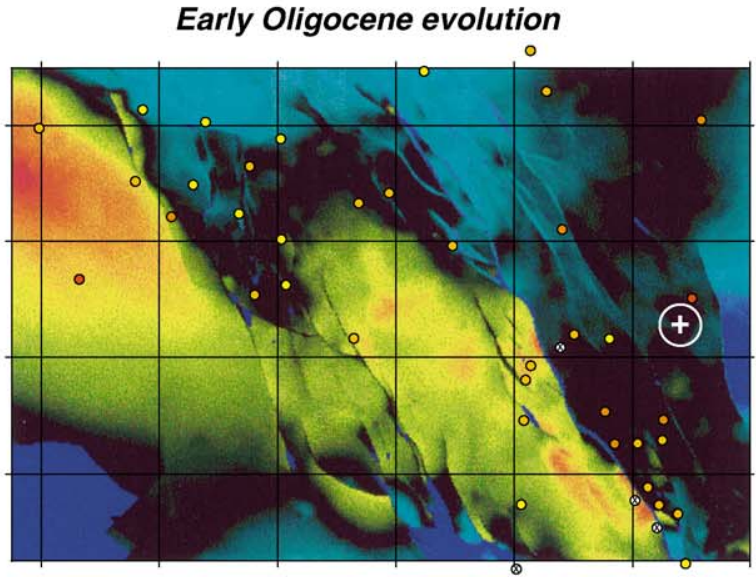

e)

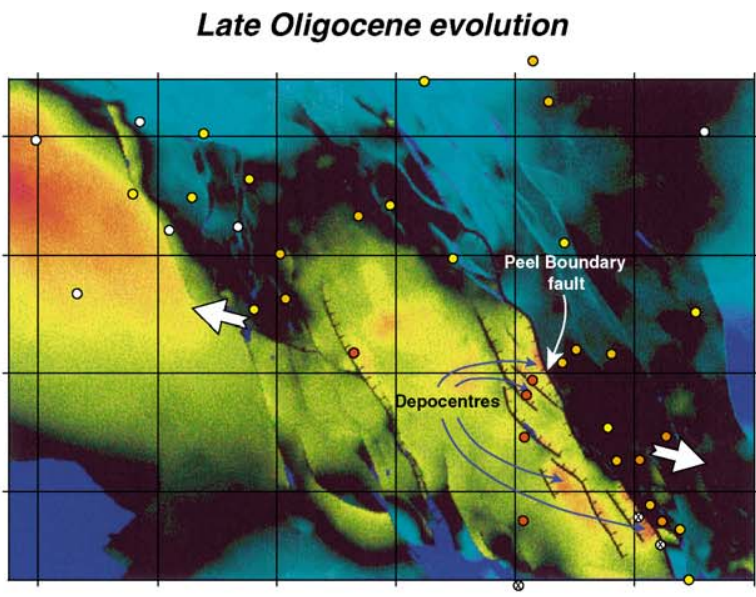

f)

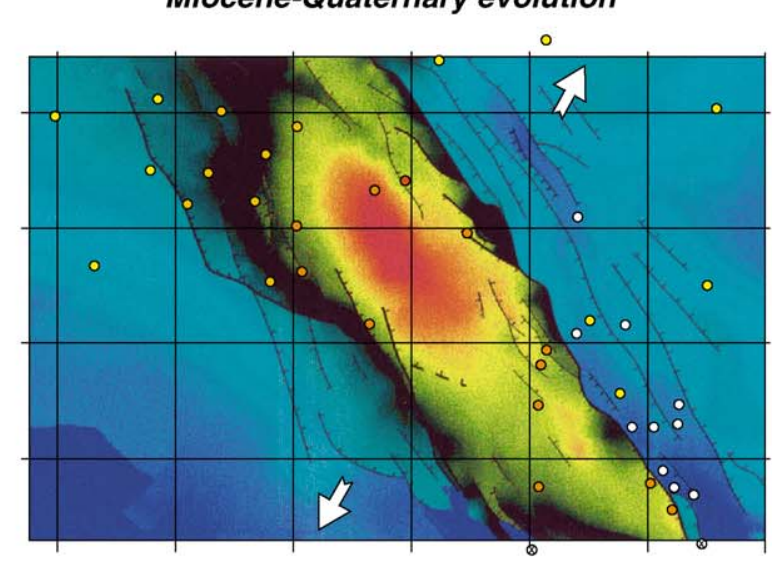

Fig. 7 (continued).

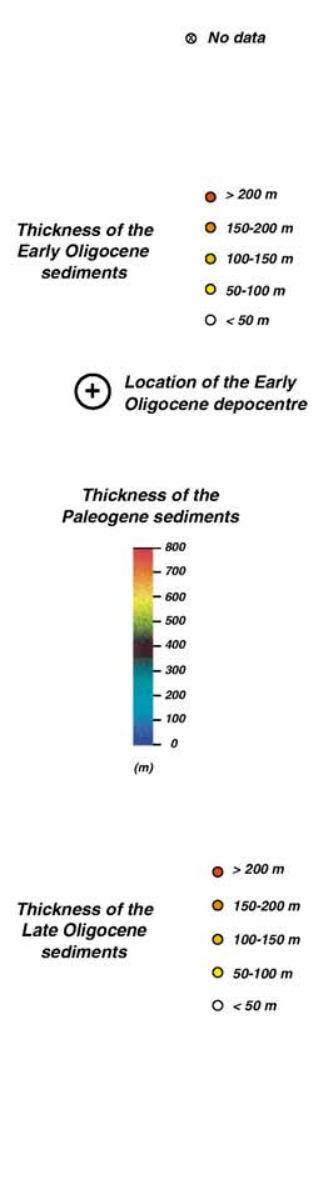

Thickness of the Neogene sediments

$$
\begin{aligned}
& \begin{array}{l}
-1200 \\
-1100 \\
-1000 \\
-000
\end{array} \text { Thickness of the } \\
& 0>1000 \mathrm{~m}
\end{aligned}
$$

O $<250 \mathrm{~m}$ 
during this period. Because the geological inheritance is always reactivated during the evolution of the RVRS, the determination of the paleo-stress field is uncertain. Nevertheless, we interpret the narrow deformation as the result of a WNW-ESE oblique extension which has only affected the southeastern part of the graben.
After the regressive phase at the Oligocene-Miocene boundary and a short stop in the sedimentation during the Aquitanian (Verbeek et al., 2002), deformation was extended to the northwestern part of the RVG where a main depocentre developed (Fig. 7f). Seismic data show the development of onlap and downlap (Fig. 8b), which are interpreted in terms of

a)
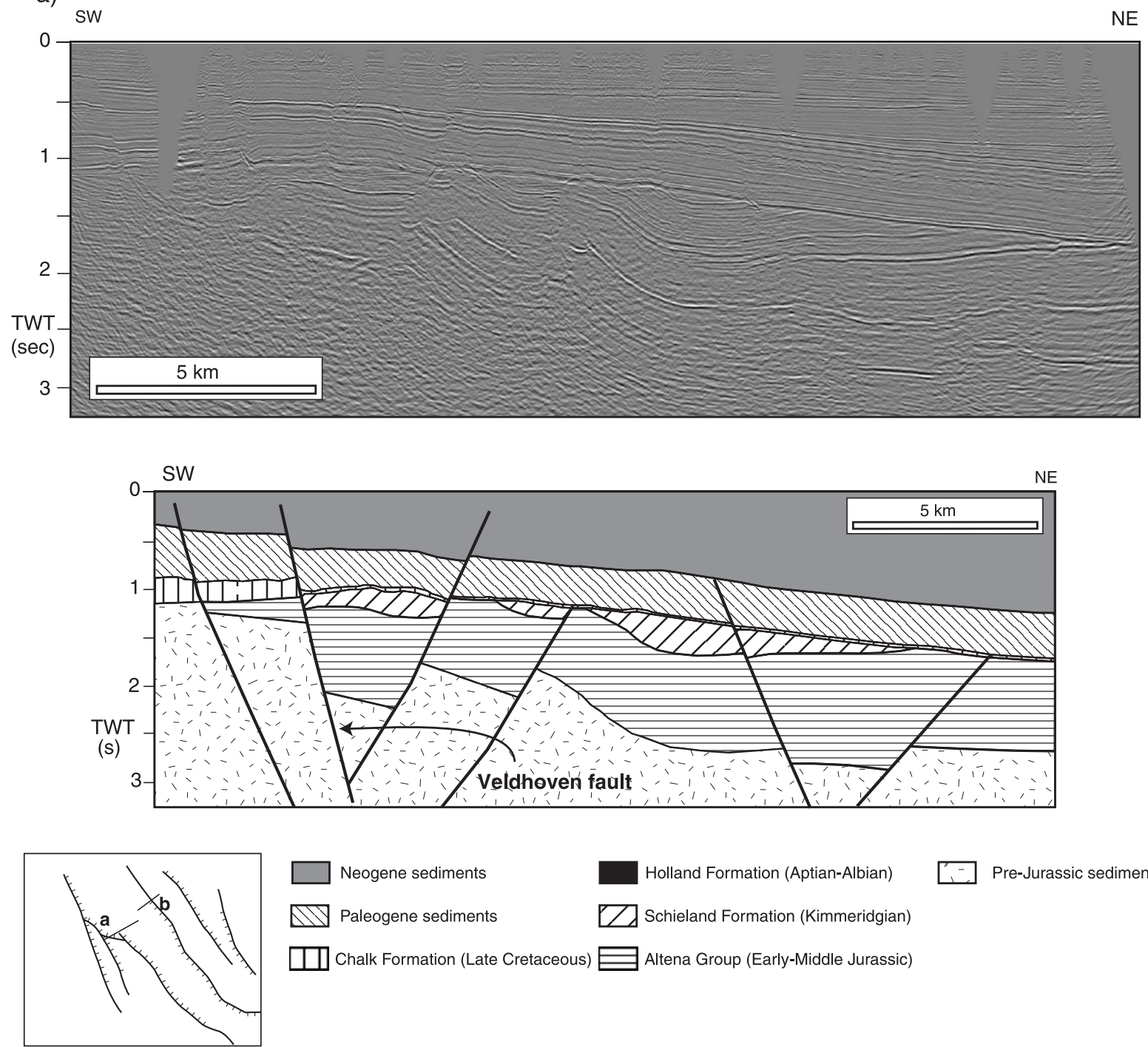

Neogene sediments
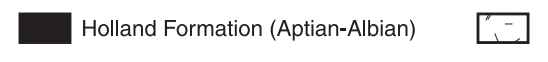

Pre-Jurassic sediments

DValeogene sediments

$\square$ Schieland Formation (Kimmeridgian)

$\square \square$ Chalk Formation (Late Cretaceous)

Altena Group (Early-Middle Jurassic)

Fig. 8. Seismic lines and structural profiles perpendicular to the Peel Boundary (a) and the Veldhoven (b) faults. The contrasted thickness of the Late Cretaceous and Neogene sediments demonstrate that the graben border faults were active during each in reverse and normal faulting mode, respectively. 


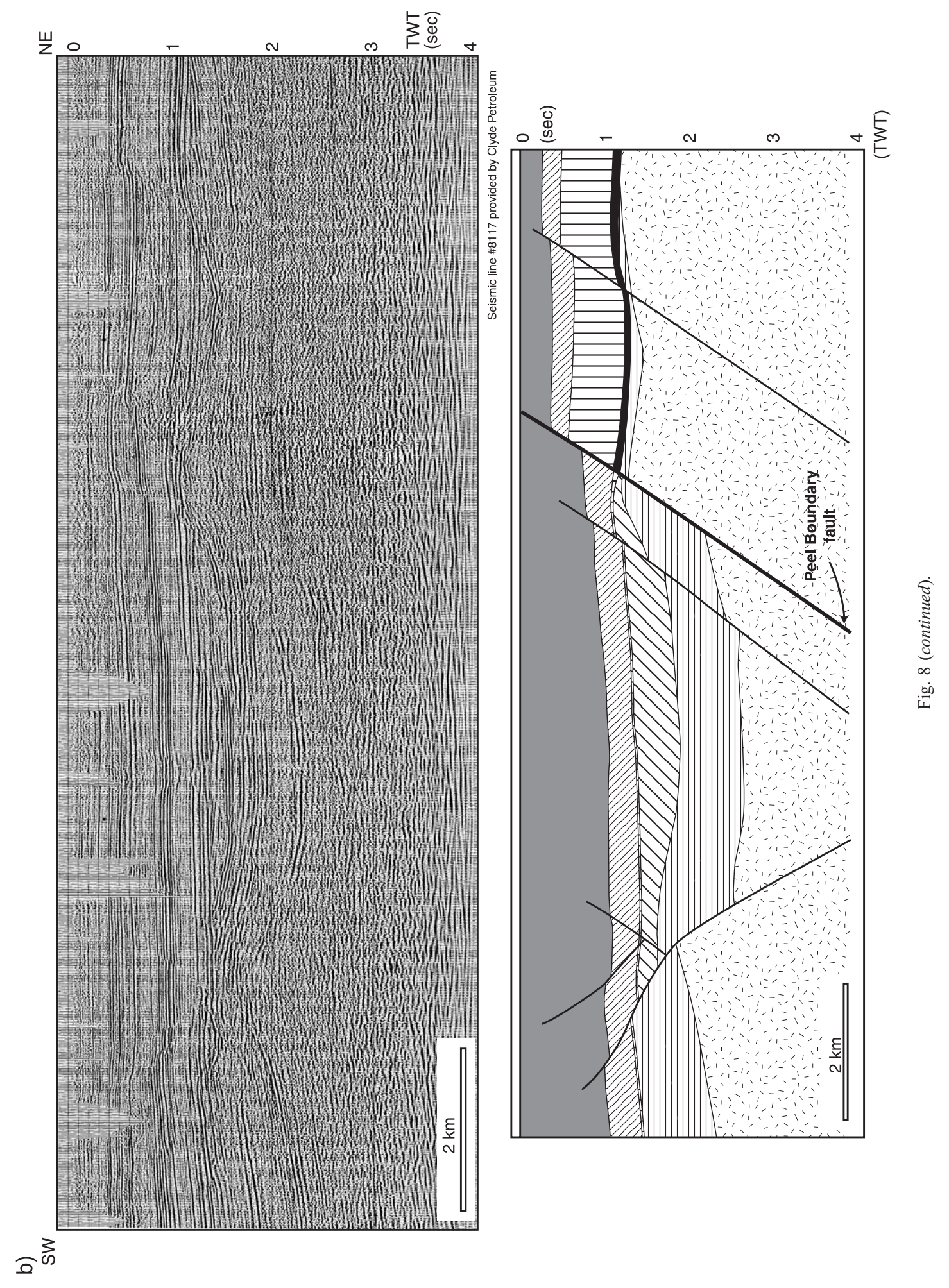


sea-level variations and an increase of the subsidence during the Burdigalian (Verbeek et al., 2002). A similar increase of the subsidence occurred contemporaneously in the northern part of the URG (Sissingh, 1998). Contrary to the Late Oligocene evolution, the oblique orientation was strongly reactivated especially along the Veldhoven fault zone. The resulting distribution is characterized by two main trends: the N145-160 trend corresponding to the general orientation of the graben, and the N110-120 oblique orientation. It is noteworthy that the offsets resulting from the N110-120 and N145-160 faults in the northwestern part of the Peel Boundary fault zone are similar. This indicates a direction of extension corresponding to the bissectrix of these two orientations (i.e., NE-SW). Extension has also induced the formation of two depocentres: a main depocentre in the northwestern part of the RVG and a minor one in the southeastern part. The western limit of the main depocentre is parallel to the N150 trend represented by the Feldbiss fault zone. In the south, the depocentre boundary is superimposed on the Jurassic Veldhoven fault zone. Seismic profiles which cross-cut this Mesozoic fault show that the southeastern prolongation of the Miocene Veldhoven fault zone controls the deformation, inducing a flexure of the Miocene sediments. To sum up, the Miocene subsidence of the RVG was controlled by two oblique orientations (N145-160 and N110-120). The orientation of the active faults and the development of the main depocentre at the intersection of two oblique main faults can be interpreted as the result of a NE-SW extension. In addition, the superimposition of the Miocene and Pleistocene depocentres (Houtgast and Van Balen, 2000) suggests a continuous extension with the same stress field. Analysis of the earthquake focal mechanism data also shows that the RVRS is affected by a present-day NE-SW extension related to a nearly vertical greatest principal stress $\left(\sigma_{1}\right)$ (Plenefisch and Bonjer, 1997).

\section{Discussion and conclusions}

One aim of our study is to integrate the evolution of the RVRS at the European scale. Nevertheless, it is beyond the scope of this paper to describe in detail the evolution of the different provinces and grabens of the
North Sea and West European rift (WER), which have been extensively studied during the past decades (e.g., Ziegler, 1988, 1992a,b; Merle et al., 1998; Sissingh, 1998; Michon, 2001). The southern limit of the considered area corresponds to the southern part of the Massif Central. South of this province (southeastern France), the extension related to the formation the WER has only induced a very weak subsidence (Hippolyte et al., 1993), whereas the area was mainly affected by the strong extension generated by the rotation of the Corsica-Sardinia block since the Late Oligocene (e.g., Seranne, 1999). In the north, the studied area is limited to the southern part of the North Sea where the deformation was influenced by both the rifting stage linked to the Atlantic rifting and the compressive stress generated by the EuropeAfrica collision (Ziegler, 1990). In our restricted area, we distinguish six successive periods during the Cenozoic evolution with analogy with the periods determined in the RVRS (only the distinction for the Eocene and Oligocene periods present minor differences).

\subsection{Early Paleocene}

The Early Paleocene evolution of the RVRS was characterized by graben inversion and the reactivation of the Mesozoic faults in a reverse faulting mode (Fig. 7a). The southern North Sea basins (the West Netherlands Basin, the Broad Fourteens Basin, the Sole Pit Basin and the southern part of the Central graben) were also affected by an inversion phase regarded as the result of a main $\mathrm{N}-\mathrm{S}$ compression (Ziegler, 1992a; Oudmayer and De Jager, 1993; Brun and Nalpas, 1996; Van Balen et al., 2000; de Lugt et al., 2003). During this period, a Late Cretaceous-Paleocene late-rifting stage linked to the Faroe-Norwegian-Greenland Sea rift system induced extension in the northern and central North Sea (Ziegler, 1992a) (Fig. 9). South of the RVRS, evidences of doming and graben inversion (Meyer et al., 1983; Malkovsky, 1987; Le Griel, 1988; Lefort and Agarwal, 1996; Roure and Coletta, 1996; Peterek et al., 1997; Barbarand et al., 2002) suggest that the deformation was induced by a $\mathrm{N}-\mathrm{S}$ compression, like in the southern North Sea. At the European scale, this compression is contemporaneous with the closure of the oceanic Piemont (Ziegler and Roure, 1996) and the Eo-Alpine 


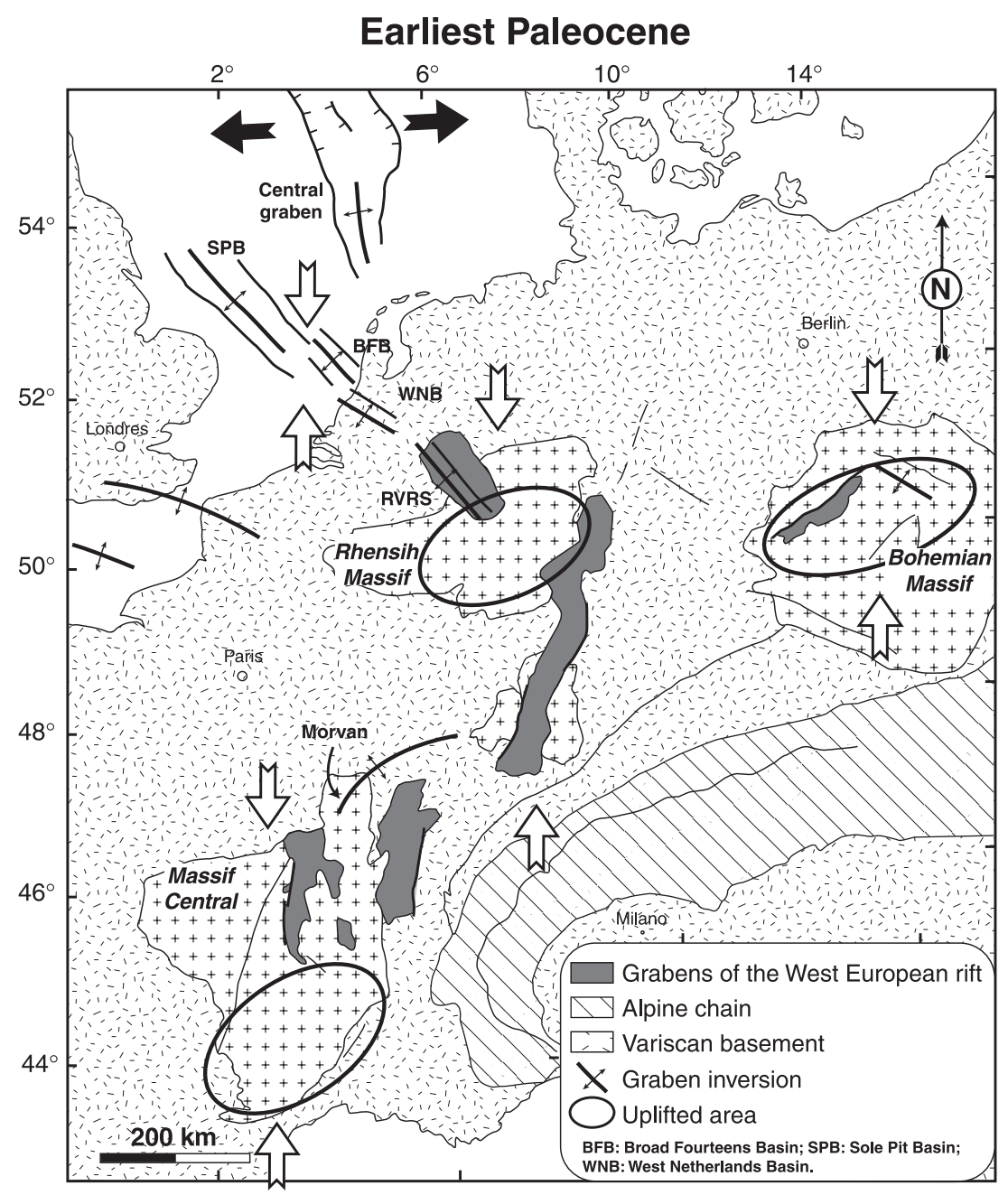

Fig. 9. Early Paleocene inversion associated to the $\mathrm{N}-\mathrm{S}$ collision between Europe and Africa (Laramide phase). White arrows: direction of compression. Black arrows: direction of extension.

compressive phase (Michon and Merle, 2001). Consequently, the synchronicity of the beginning of the continental collision events and the inversion phases could suggest that during the first step of a continentcontinent collision the stress is directly propagated in the adjacent plate.

\subsection{Late Paleocene}

For the Late Paleocene period, the lack of precise information, mainly due to the continental paleogeography of western Europe, renders a determination of
Late Paleocene deformation south to the RVRS difficult. In the RVRS, our study shows that this period was characterized by subsidence and minor fault activity (Fig. 7b). In the North Sea basins, this evolution is similar (Ziegler, 1992a; Oudmayer and De Jager, 1993; de Lugt et al., 2003) and it has been attributed to the continuous late-rifting process in the northern Atlantic (Ziegler, 1992a) or a lithospheric relaxation after the Early Paleocene inversion (de Lugt et al., 2003). During this period, the RVRS then corresponded to the southern end of the North Sea rift system (Fig. 10). 


\section{Late Paleocene}

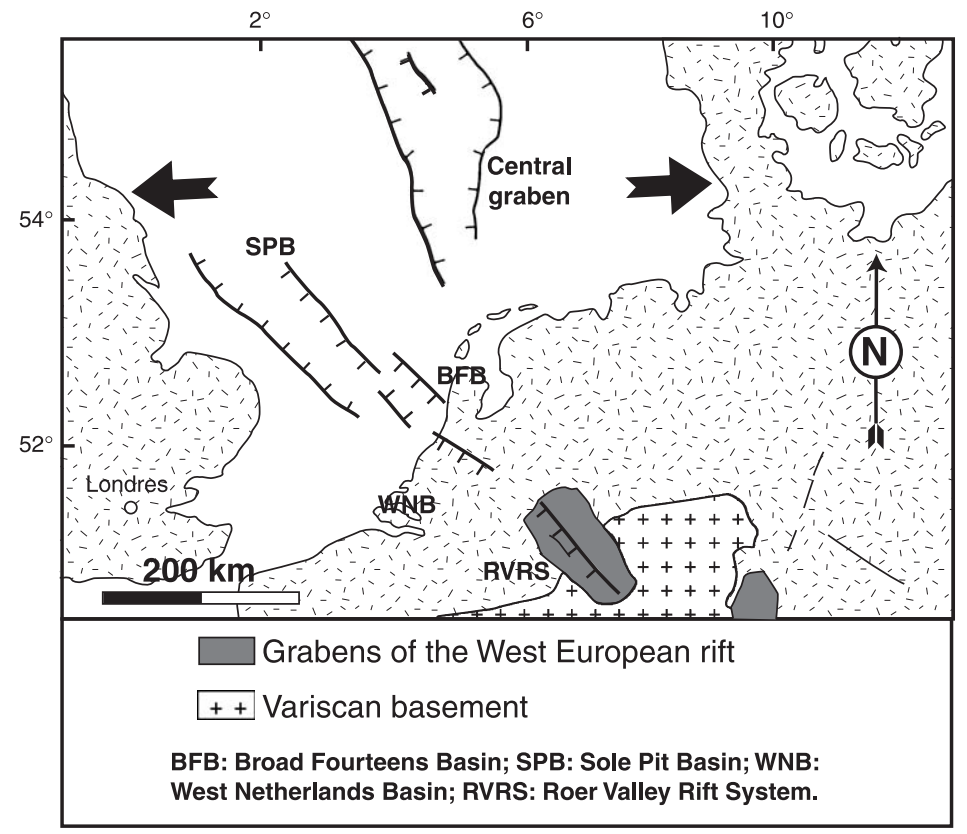

Fig. 10. Late Paleocene subsidence of the southern North Sea basins generated by lithosphere relaxation after the Laramide inversion (de Lugt et al., 2003) and/or by a late-rifting stage related to the rifting in North Atlantic between Greenland and the Fareoe Islands (Ziegler, 1992a,b).

\subsection{Early Eocene}

The Early Eocene sedimentation was probably partly eroded in the RVRS during the Late Eocene doming. In the southern North Sea, subsidence has induced an important sedimentation with minor fault activity (de Lugt et al., 2003), suggesting a thermal subsidence after the late-rifting stage or continued sagging due to stress relaxation, which ended at the end of the Paleocene (Ziegler, 1992a). In southwestern Europe, in the larger WER area, two sediment facies are attributed to the Early Eocene period: the Siderolithic formation and the Lutetian continental sedimentation (e.g., Rat, 1974; Sissingh, 1998). The Siderolithic formation, which results from the in-situ erosion of the outcropping rock has a widespread distribution from the Upper Rhine Graben area up to the Massif Central (Sissingh, 1998; Michon, 2001). The Lutetian continental sedimentation outcrops in the northern Upper Rhine Graben and the Massif Central or outside the grabens (Fig. 11). This spatial distribution suggests that the Lutetian sedimentation did not result from a period of subsidence linked to the Late Eocene-Oligocene rifting phase but rather from the development of local lakes in a peneplain domain. To sum up, these data suggest that the Early Eocene period corresponds to a tectonically quiet period in the North Sea and the WER.

\subsection{Late Eocene}

Compared to the Early Eocene evolution, the Late Eocene period was characterized by intensive and opposite deformation in the southern North Sea and the WER. The southern North Sea basins were affected by a second phase of inversion, whereas this period corresponds to the onset of the rifting event in the WER (Fig. 12). In the southern North Sea and the Channel area, reactivation of the Mesozoic and Cenozoic faults in a reverse faulting mode (Oudmayer and De Jager, 1993; Van Balen et al., 2000; de Lugt et al., 2003) has been interpreted as resulting from a nearly $\mathrm{N}-\mathrm{S}$ compression related to the Pyrenees formation (Ziegler, 1990). In contrast, the Late Eocene sedimentation in the Massif Central graben (Merle et al., 1998), the central part of the 


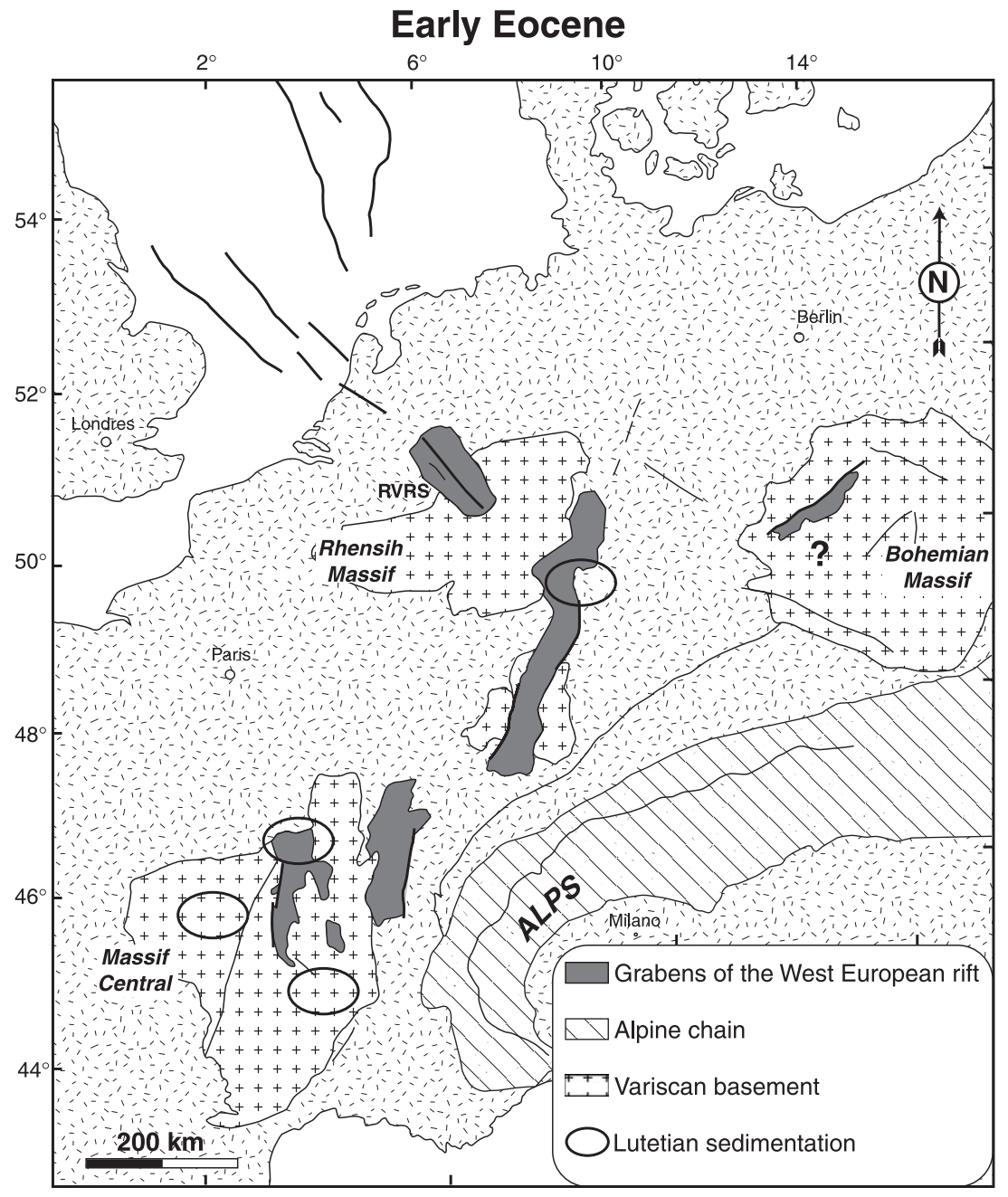

Fig. 11. Early Eocene evolution characterized by a thermal subsidence in the southern North Sea and a continental sedimentation in the Alpine foreland. ? represents a lack of data concerning this period in the Bohemian Massif.

URG (Sissingh, 1998; Schumacher, 2002) and the Eger graben (Chlupac et al., 1984) proves that the WER was affected by extension during this period. Based only on microtectonic data obtained in the Variscan basement and the Triassic-Jurassic formations, Villemin and Bergerat (1987) proposed that this early period of extension resulted from a N-S compression. Nevertheless, in the main grabens of the WER, the fault orientation and the shape of the depocentres allow precise characterization of the paleo-stress field, which has caused the graben development. In the Limagne graben and the URG where the subsidence was controlled by the reactivation of oblique Variscan faults (Michon, 2001; Schumacher, 2002), the location of the depocentres at the intersection of the main faults and their crescent shape suggest an $\mathrm{E}-\mathrm{W}$ extension for the Limagne graben (i.e., the Massif Central rift) and an ESE-WNW/ SE-NW extension in the URG. These directions of extension are confirmed by recent analogue experiments, which show that (1) the shape of the depocentres is directly controlled by the stress-field and (2) crescent shape depocentres are only created with direction of extension corresponding to the bissectrix 


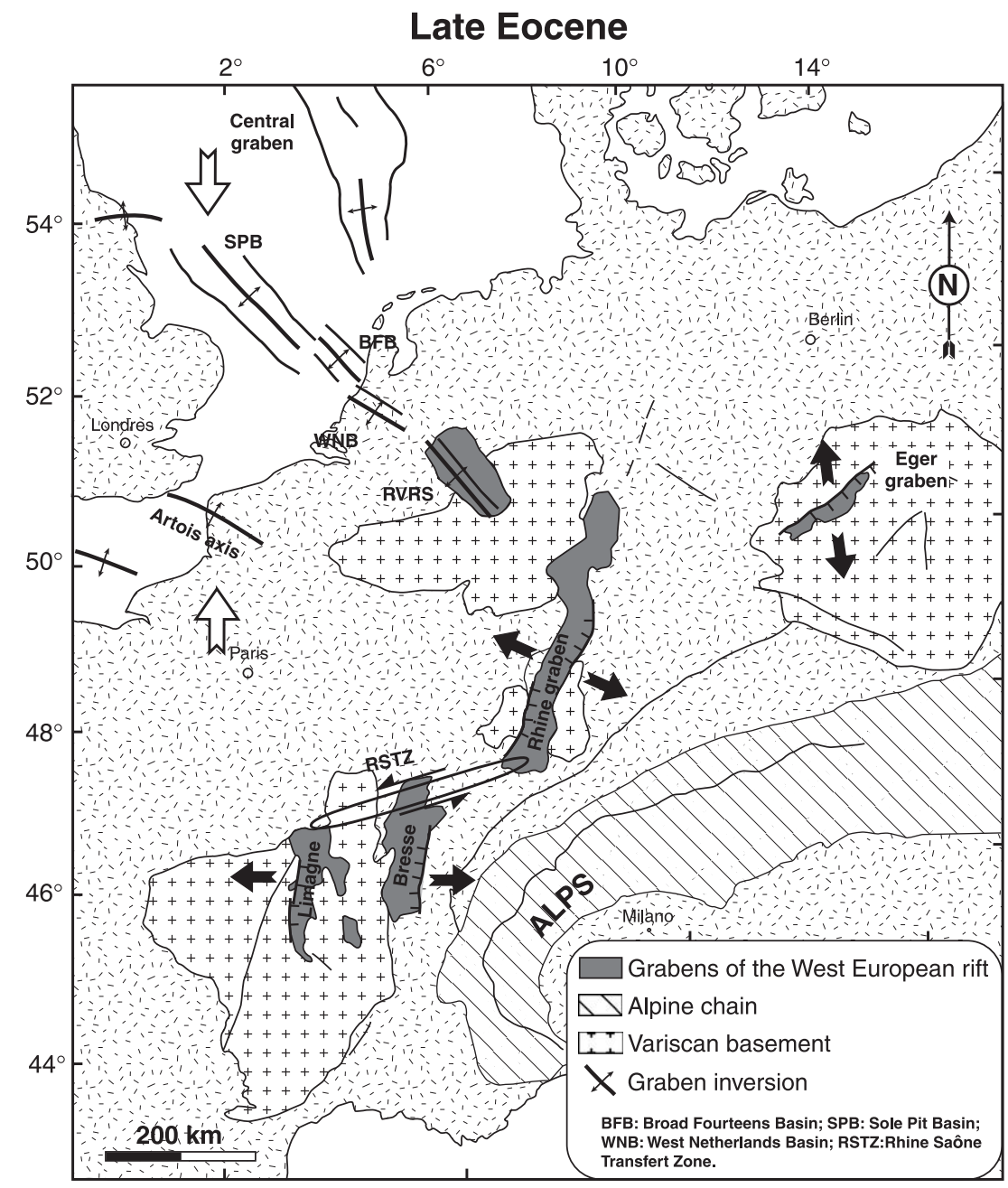

Fig. 12. Late Eocene inversion phase in the southern North Sea basins and the Channel area (Pyrenean phase) related to the collision between Europe and Africa. This inversion is coeval with the onset of the rifting in the West European rift.

of the oblique faults (Michon and Sokoutis, in prep). As the age of the deformation is poorly constrained by the microtectonic approach, we propose that the $\mathrm{N}-\mathrm{S}$ compression deduced by Villemin and Bergerat (1987) is more likely related to the Early Paleocene main compression than to the Late Eocene event, which has induced uplift and inversion in the southern North Sea basins and the Channel only.

In the Eger graben, Variscan faults were also reactivated (Malkovsky, 1987). The maximum thickness of the sediments along the main N60E fault (Malkovsky, 1987) suggests that this fault has controlled the subsidence by a normal faulting mode resulting from a nearly $\mathrm{N}-\mathrm{S}$ extension. Consequently, in the WER, the direction of extension inferred from strongly constrained data suggest a clockwise rotation of the direction of extension towards the east (Michon, 2001) (Fig. 12).

\subsection{Oligocene}

According to microtectonic studies (e.g., Villemin and Bergerat, 1987), the Oligocene is marked by changes in the stress field with a general E-W extension during the Rupelian and a NE-SW compression during the Chattian. However, the super- 
position and the similar shape of the Late Eocene and Oligocene (Rupelian and Chattian) main depocentres in the Massif Central grabens and the central part of URG suggest a constant direction of extension during the Late Eocene and the Oligocene. At a European scale, the Oligocene evolution corresponds to a propagation of the extension related to the WER towards the north and a stop of the inversion phase in the southern North Sea basins (Fig. 13). North to the URG, the RVRS subsidence resumed in the Early Oligocene and accelerated in the Late Oligocene (Fig. $7 \mathrm{~d}, \mathrm{e})$. In the northeastern part of the Paris Basin, the deformation linked to the extension was also recog- nized and the average direction of extension was NW-SE (Coulon, 1992). In the southern North Sea, the Oligocene corresponds to a phase of subsidence due to thermal relaxation of the lithosphere and sedimentary load, without or with minor fault activity (Ziegler, 1990; Oudmayer and De Jager, 1993; de Lugt et al., 2003). Contrary to this quiescent evolution, the Channel area and the northern end of the Paris basin were affected by inversion especially during the Late Oligocene and the Early Miocene (Lake and Karner, 1987; Ziegler, 1990).

Two main mechanisms were proposed to explain the formation of the WER. The development of the

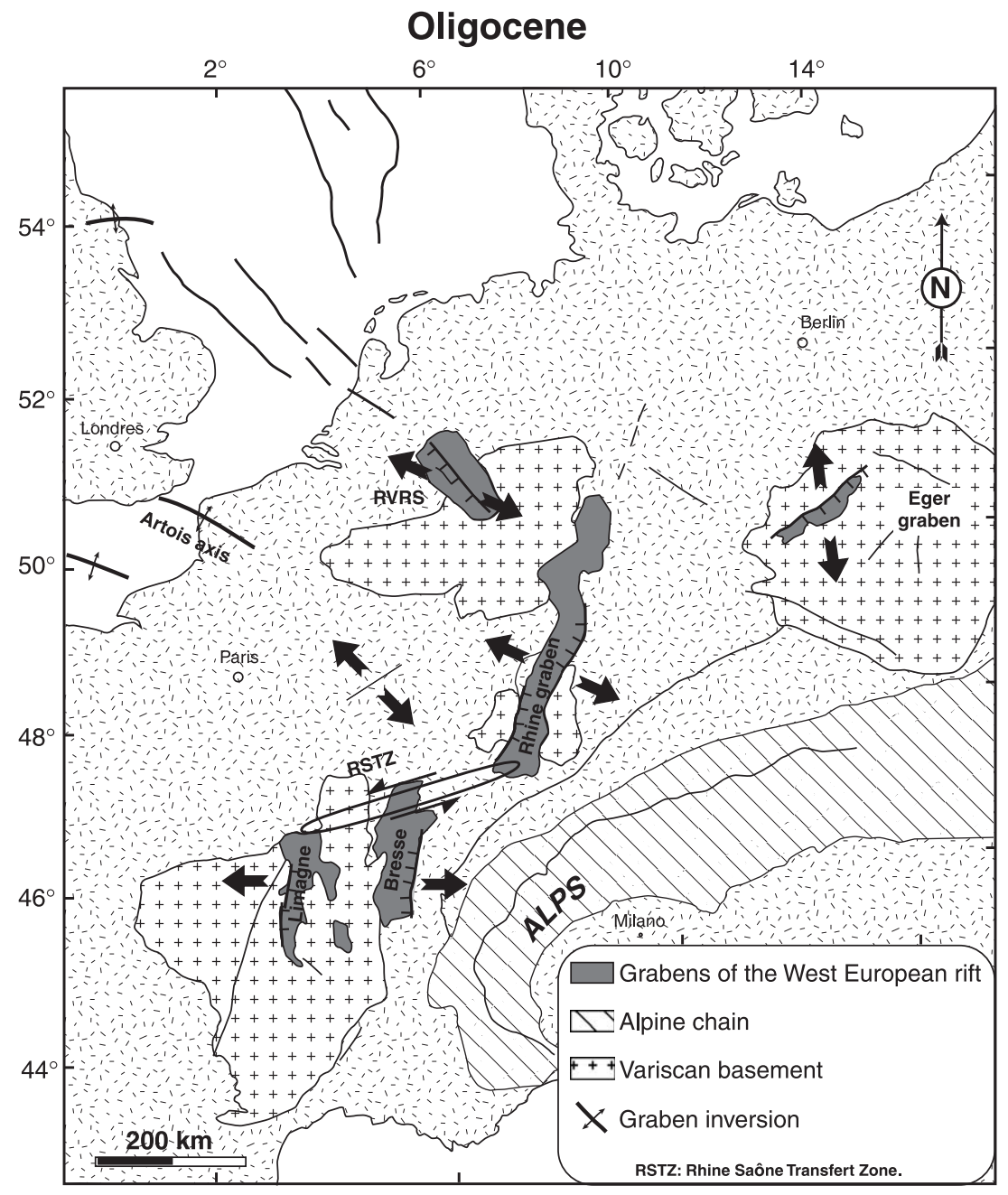

Fig. 13. Oligocene extension in the West European rift and thermal subsidence in the southern North Sea basins. 
WER during the Late Eocene-Oligocene could result from the combined effect of the $\mathrm{N}-\mathrm{S}$ Alpine compression and the opening of the northern Atlantic (e.g., Tapponnier, 1977). In the alternative model, the WER was induced by successive phases of compression and extension initiated by far field stresses (e.g., Bergerat, 1985; Ziegler, 1992b). In both models, only the western part of the WER is considered (i.e., the Massif Central grabens and the Rhine graben) and the Oligocene direction of extension is supposed to be $\mathrm{E}-\mathrm{W}$ at a European scale. However, geological data indicate that the direction of extension was not E-W at a European scale but perpendicular to the direction of shortening in the Alpine mountain chain (see Fig. 2a in Lickorish et al., 2002) (Fig. 14). Assuming that the global stress field was characterized by a $\mathrm{N}-\mathrm{S}$ compression caused by the collision between African and European plates, the formation of the WER with a $\mathrm{N}-\mathrm{S}$ extension in the Bohemian massif is hard to explain.

We propose herein a working hypothesis in which the role of the stress field generated by the formation of the Alpine mountain chain is taken into account. It is worth to note that the Late Eocene-Oligocene period corresponds to a phase of strong deformation in the Alpine chain with the formation of the eclogitic rocks (i.e., HP metamorphism) (Monié and Philippot, 1989; Tilton et al., 1991; Duchêne et al., 1997). Kinematic data show that the directions of crustal displacement were $\mathrm{E}-\mathrm{W}$ in the western Alps, NW$\mathrm{SE}$ in western Switzerland and probably $\mathrm{N}-\mathrm{S}$ in the central Alps during this period (Lickorish et al., 2002). It seems reasonable to assume that the direction of crustal displacement was similar to and mainly controlled by the direction of continental subduction. Then, the Eocene-Oligocene period was likely

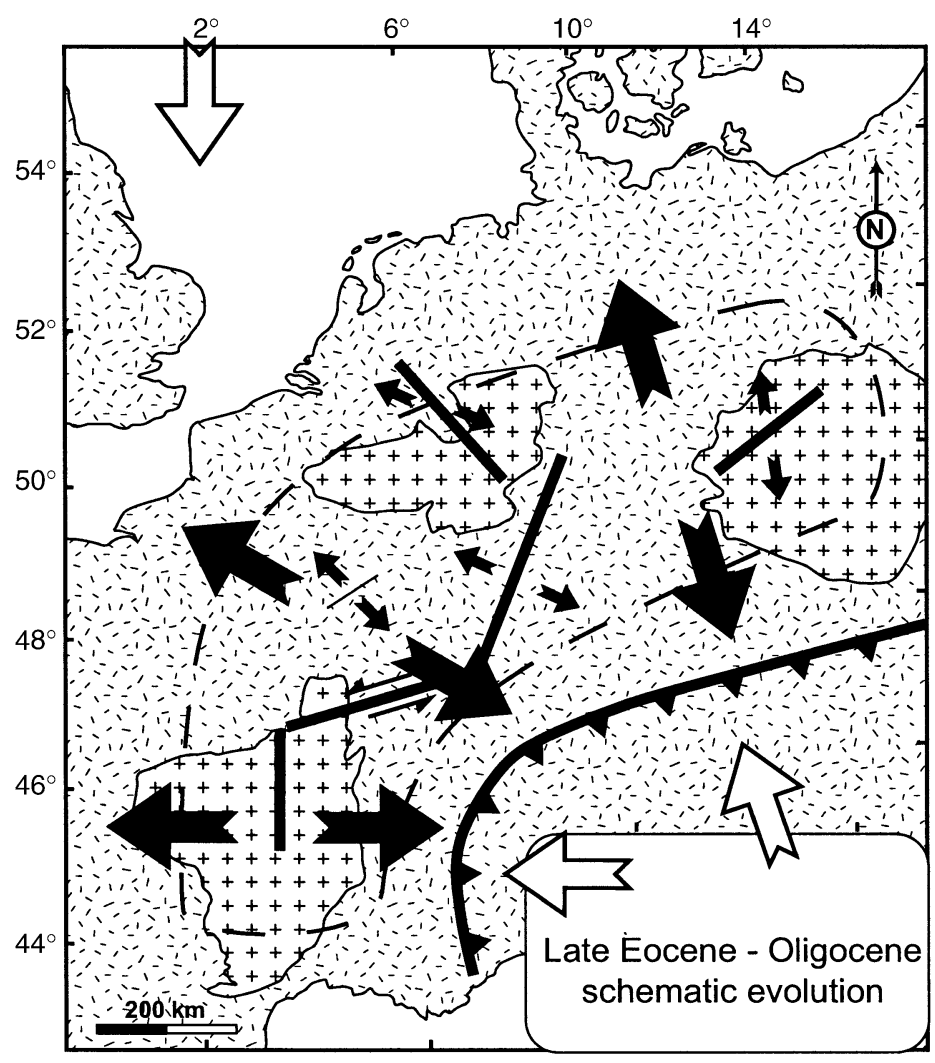

Fig. 14. Schematic representation of the Late Eocene-Oligocene rifting in the WER. Geological data show that the direction of extension is E$\mathrm{W}$ in the Massif Central and presents a clockwise rotation towards the East (nearly N-S in the Eger Graben). See text for explanation. 
marked by the development of a N-S deep lithospheric root in the western Alps and a E-W lithospheric root in the central Alps, similar to the presentday geometry of the Alpine lithospheric root (Babuska et al., 1990). It has been shown that the formation of a deep lithospheric root can produce a downward gravitational force, which may induce extension in the adjacent lithosphere (Fleitout, 1984). In such a model, the direction of extension is perpendicular to the lithospheric root. In consequence, we speculate that the formation of the Alpine lithospheric root during the Eocene-Oligocene period could have induced the formation of the WER, as already proposed by Merle and Michon (2001). This model, where a "local" effect (i.e., the downward gravitational stress due to the formation of the lithospheric root) causes the formation of the WER, does not contradict the overall $\mathrm{N}-\mathrm{S}$ compression, which has induced inversion in the southern North Sea and the Channel. The magnitude of stress generated by each process would have

\section{Miocene-Quaternary}

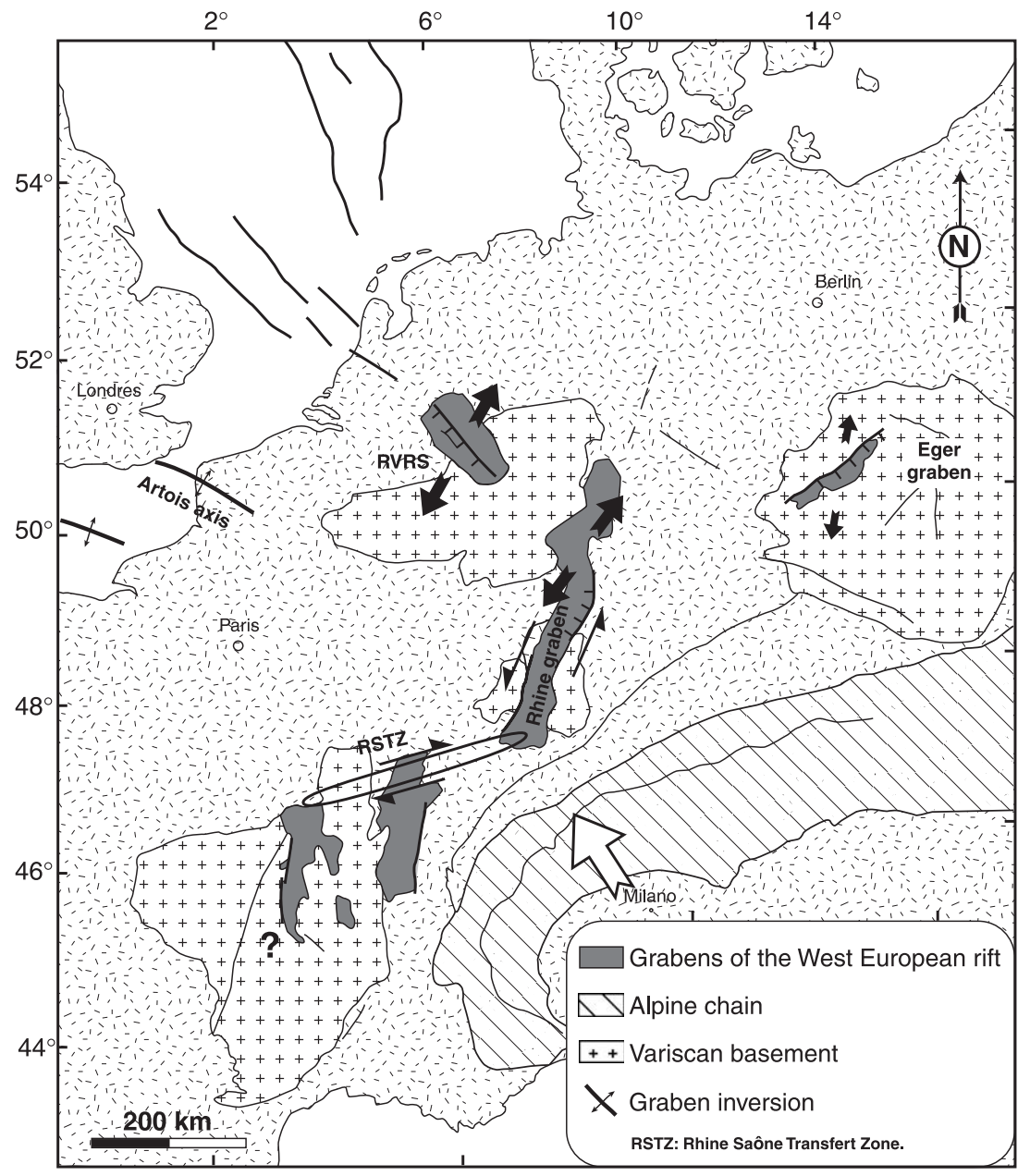

Fig. 15. Miocene-Quaternary evolution of western Europe. In the RVRS, the URG and the Eger graben, the fault orientation and the shape of the depocentres indicate a rotation of the direction of extension at the Oligocene-Miocene transition. A slight inversion and a thermal subsidence characterized the evolution of the Channel area and the North Sea basins, respectively. 
controlled the location of the areas affected by compression or extension.

\subsection{Miocene-Quaternary}

The RVRS, the Eger graben and the URG subsided more or less continuously during the Oligocene-Quaternary evolution. However, the Oligocene-Miocene transition was marked by a radical change in the European geodynamics. In the RVRS, the northwestward migration of the depocentre and the orientation of the most active faults indicate a counter clockwise rotation of $70-80^{\circ}$ of the direction of extension (i.e., NE-SW extension) (Fig. 15). A similar rotation has been described for the northern part of the URG where new depocentres developed (Meier and Eisbacher, 1991; Schumacher, 2002). These new depocentres are interpreted in terms of pull-apart basins resulting from sinistral strike slip faulting (Illies, 1981). In the Eger graben, the depocentre shapes in the Cheb sub-basin, which are different for the Late Oligocene-Earliest Miocene and Miocene-Pliocene periods (Spicakova et al., 2000), suggest a change of the stress field around the Oligocene-Miocene transition and an identical stress field for the Middle Miocene and Late Pliocene periods. In the Massif Central, the Miocene-Quaternary evolution was characterized by a strong uplift of the whole area, which makes a determination of the regional stress field in this province difficult. Preservation of Miocene sediments below lava flows shows that the complete Miocene sedimentation was very thin and restricted to elongated narrow lakes parallel to the grabens (Hugueney et al., 1999). In the Bresse graben, although sedimentation developed during the Miocene-Quaternary evolution, a westward propagation of the Alpine flexural basin was proposed to explain this subsidence (Merle et al., 1998). Finally, the displacement along the Rhine-Saône transfer zone, which was a left lateral fault zone during the Late Eocene and the Oligocene, has changed at the Oligocene-Miocene transition and became right lateral (Laubscher, 2001).

In the north, the southern North Sea basins continued to subside during this period. Seismic data reveals that minor fault activity has affected the Neogene sediments (Brun and Nalpas, 1996; Van Balen et al., 2000), suggesting a continuous thermal subsidence. Nevertheless, the acceleration of the subsidence from the Pliocene could be explained by an accentuation of the thermal subsidence by a NW-SE in-plane force (Van Balen et al., 1998). Whatever the origin of this subsidence increase, geological and geophysical data clearly show that the tectonic activity related to the evolution of the WER stops in the northern end of the RVRS (Fig. 1). In the Channel area, inversion was maximum during Early Miocene but is still ongoing during the Quaternary (Ziegler, 1990).

Geological and geophysical data indicate that the present-day stress field in western Europe is characterized by a NW-SE to NNW-SSE maximum compressive stress (Müller et al., 1992; Plenefisch and Bonjer, 1997). Analysis of the earthquake focal mechanism data in the UGR and the RVRS shows that this maximum compressive stress induces left lateral displacement in the southern and central URG, whereas it causes NE-SW extension in the northern end of the URG and in the RVRS (Plenefisch and Bonjer, 1997).

In consequence, we interpret the general evolution of western Europe during the Miocene-Quaternary period as the result of the NW-SE collision between Europe and Africa (Fig. 16). In this model, the URG and the RVRS concentrate the main deformation. Due to the NW-SE compression, the URG is reactivated as a strike slip structure, which induced rifting in its northern ending and in the RVRS. This leads to the individualization of two crustal domains. Although the NE-SW relative motion of these crustal domains is assessable, the lack of precise and reliable geodetic data does not allow determination of the absolute motion of each domain. One can speculate that the Baltic shield, situated east of the northeastern domain, probably prevents the northeastern motion of this block. Consequently, the southwestern crustal domain was forced to migrate toward the southwest. The subsidence in the North Sea basins could result from the northward prolongation of a diffuse extension.

One fundamental feature is the change of the global deformation of the European lithosphere at the Oligocene-Miocene transition. Assuming that the Late Eocene-Oligocene extension was induced by the formation of a deep Alpine lithospheric root, 


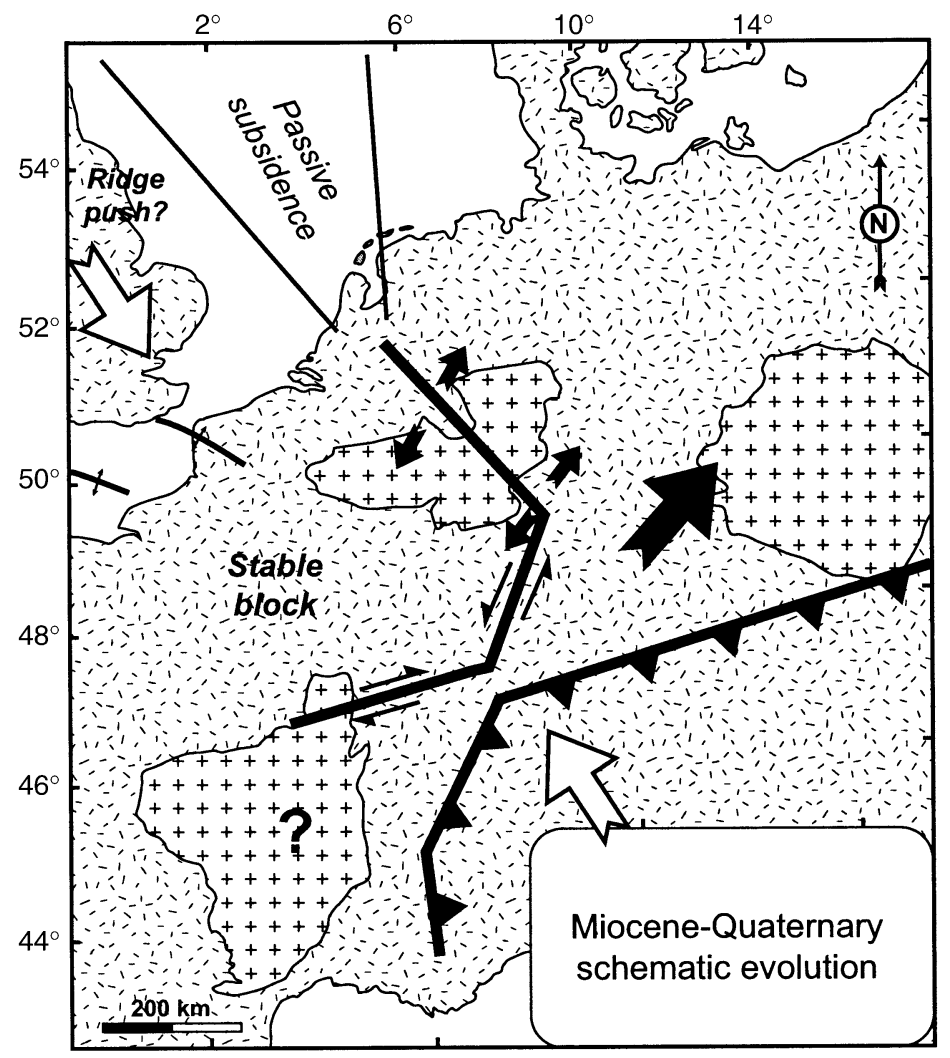

Fig. 16. Schematic evolution during the Neogene. The direction of extension could be explained by the NW-SE compression related to the Alpine collision. See text for explanation.

we propose that the Alpine chain was proned to a slab break-off at the Oligocene-Miocene transition. Such a slab break-off was already invoked by Von Blanckenburg and Davies (1995) to explain the development of the Tertiary magmatism in the central and eastern Alps between 42 and $25 \mathrm{Ma}$. However, they dated it at around $40 \mathrm{Ma}$. In the western Alps, geological data not show either magmatism or a radical change in the Alpine kinematics at this time. In contrast, the Oligocene-Miocene transition ( $25 \mathrm{Ma}$ ) corresponds to the beginning of thrusting of the external crystalline massifs and the reactivation of the Briançonnais front in normal faulting mode (Tricart et al., 2001). Then, we consider that the coeval change in the Alpine chain and western Europe could result from a slab detachment below the western Alps. This slab break-off at the Oligocene-Miocene transition could explain the stop of the Late Eocene-Oligocene extension and the development of the NW-SE maximum compressional stress, which controls the European deformation since the beginning of the Miocene.

\section{Acknowledgements}

This publication is a contribution of the Environmental Tectonic (ENTEC) European Project funded by EU (RTN-1999-00003) and the INSU IT Project "Déformations lithosphériques grande longueur d'onde cénozoïques de l'Europe de l'Ouest". P.A. Ziegler and Iwan de Lugt are thanked for interesting discussions. With the courtesy of Clyde Petroleum BV to publish several wells. Thanks are also given to Francois Roure, Jean-Pierre Burg and an anonymous reviewer who helped in the improvement of the manuscript. 


\section{Appendix A}

ROvD: Dienst der Rijksopsporing van Delfstoffen.

\begin{tabular}{|c|c|c|c|c|}
\hline Number & Name & Date & $\begin{array}{l}\text { Total } \\
\text { depth } \\
\text { (m) }\end{array}$ & \\
\hline 1 & $\begin{array}{l}\text { Werkendam-1 } \\
\text { (WED-01) }\end{array}$ & 1958 & 2275 & $\begin{array}{l}\text { Zijerveld et al. } \\
\text { (1992) }\end{array}$ \\
\hline 2 & $\begin{array}{l}\text { Waalwijk-1 } \\
\text { (WWK-01) }\end{array}$ & 1987 & 3802 & NITG-TNO (2001) \\
\hline 3 & $\begin{array}{l}\text { Oisterwijk-1 } \\
\text { (OIW-01) }\end{array}$ & 1967 & 2496 & $\begin{array}{l}\text { Zijerveld et al. } \\
\text { (1992) }\end{array}$ \\
\hline 4 & $\begin{array}{l}\text { St-Michielsgestel-1 } \\
(\mathrm{SMG}-01)\end{array}$ & 1969 & 3338 & $\begin{array}{l}\text { Zijerveld et al. } \\
\text { (1992) }\end{array}$ \\
\hline 5 & $\begin{array}{l}\text { Heeswijk-1 } \\
\text { (HSW-01) }\end{array}$ & 1992 & 2544 & Clyde Petroleum \\
\hline 6 & $\begin{array}{l}\text { Keldonk-1 } \\
\text { (KDK-01) }\end{array}$ & 1992 & 2330 & Clyde Petroleum \\
\hline 7 & $\begin{array}{l}\text { Veldhoven-1 } \\
\text { (VEH-01) }\end{array}$ & 1967 & 2124 & $\begin{array}{l}\text { Zijerveld et al. } \\
\text { (1992) }\end{array}$ \\
\hline 8 & $\begin{array}{l}\text { Asten-1 } \\
\text { (AST-01) }\end{array}$ & 1967 & 2664 & $\begin{array}{l}\text { Zijerveld et al. } \\
\text { (1992) }\end{array}$ \\
\hline 9 & $\begin{array}{l}\text { Asten-2 } \\
\text { (AST-02) }\end{array}$ & 1992 & 1673 & NITG-TNO (2001) \\
\hline 10 & $\begin{array}{l}\text { Nederweert-1 } \\
\text { (NDW-01) }\end{array}$ & 1965 & 2943 & $\begin{array}{l}\text { Zijerveld et al. } \\
\text { (1992) }\end{array}$ \\
\hline 11 & Molenbeersel-198 & 1988 & 1773 & $\begin{array}{l}\text { Demyttenaere and } \\
\text { Laga (1988) }\end{array}$ \\
\hline 12 & $\begin{array}{l}\text { Oploo-16 } \\
\text { (OPL-16) }\end{array}$ & 1913 & 1150 & $\begin{array}{l}\text { Zijerveld et al. } \\
\text { (1992) }\end{array}$ \\
\hline 13 & $\begin{array}{l}\text { America-11 } \\
\text { (ACA-11) }\end{array}$ & 1910 & 1201 & $\begin{array}{l}\text { Zijerveld et al. } \\
\text { (1992) }\end{array}$ \\
\hline 14 & $\begin{array}{l}\text { Neer-71 } \\
\text { (NER-71) }\end{array}$ & 1953 & 1293 & DSM Energie \\
\hline 15 & $\begin{array}{l}\text { Elmpt-77 } \\
\text { (EPT-77) }\end{array}$ & 1958 & 1215 & DSM Energie \\
\hline 16 & $\begin{array}{l}\text { Melick- } \\
\text { Herkenbosch-70 } \\
\text { (MHB-70) }\end{array}$ & 1955 & 524 & NITG-TNO (2001) \\
\hline 17 & $\begin{array}{l}\text { Arcen-1 } \\
\text { (ARC-01) }\end{array}$ & 1987 & 888 & $\begin{array}{l}\text { Rijks Geologische } \\
\text { Dienst }\end{array}$ \\
\hline 18 & $\begin{array}{l}\text { Beesel-72 } \\
(\text { BEE-72) }\end{array}$ & 1954 & 1234 & DSM Energie \\
\hline 19 & $\begin{array}{l}\text { Belfeld-14 } \\
\text { (BFD-74) }\end{array}$ & 1911 & 1202 & $\begin{array}{l}\text { Zijerveld et al. } \\
\text { (1992) }\end{array}$ \\
\hline 20 & $\begin{array}{l}\text { Broekzijde-1 } \\
\text { (BKZ-01) }\end{array}$ & 1989 & 2703 & Clyde Petroleum \\
\hline 21 & $\begin{array}{l}\text { Cornelishof-4 } \\
\text { (CNH-04) }\end{array}$ & 1905 & 679 & ROvD \\
\hline 22 & $\begin{array}{l}\text { Dongen-1 } \\
\text { (DON-01) }\end{array}$ & 1997 & 1542 & $\begin{array}{l}\text { Zijerveld et al. } \\
\text { (1992) }\end{array}$ \\
\hline 23 & Dorothea-1 & 1907 & 309 & $\begin{array}{l}\text { Krusch and } \\
\text { Wunstorf (1907) }\end{array}$ \\
\hline
\end{tabular}

Appendix A (continued)

\begin{tabular}{|c|c|c|c|c|}
\hline Number & Name & Date & $\begin{array}{l}\text { Total } \\
\text { depth } \\
(\mathrm{m})\end{array}$ & \\
\hline 24 & Emmerich-1 & 1962 & 1449 & $\begin{array}{l}\text { Elberskirch and } \\
\text { Wolburg (1962) }\end{array}$ \\
\hline 25 & $\begin{array}{l}\text { Helden-75 } \\
\text { (HDN-75) }\end{array}$ & 1955 & 1353 & NITG-TNO (2001) \\
\hline 26 & $\begin{array}{l}\text { Helenaveen-7 } \\
\text { (HEL-07) }\end{array}$ & 1907 & 1155 & ROvD \\
\hline 27 & $\begin{array}{l}\text { Hilvarenbeek-1 } \\
\text { (HVB-01) }\end{array}$ & 1995 & 2621 & Clyde Petroleum \\
\hline 28 & $\begin{array}{l}\text { Kerkwijk-1 } \\
(\text { KWK-01) }\end{array}$ & 1988 & 3281 & NITG-TNO (2001) \\
\hline 29 & $\begin{array}{l}\text { Liessel-22 } \\
\text { (LIE-22) }\end{array}$ & 1915 & 1332 & $\begin{array}{l}\text { Zijerveld et al. } \\
\text { (1992) }\end{array}$ \\
\hline 30 & $\begin{array}{l}\text { Loon op Zand-1 } \\
\text { (LOZ-01) }\end{array}$ & 1953 & 3062 & $\begin{array}{l}\text { Zijerveld et al. } \\
\text { (1992) }\end{array}$ \\
\hline 31 & $\begin{array}{l}\text { Maasbommel-2 } \\
\text { (MSB-02) }\end{array}$ & 1966 & 1278 & $\begin{array}{l}\text { Zijerveld et al. } \\
\text { (1992) }\end{array}$ \\
\hline 32 & $\begin{array}{l}\text { Maasniel-74 } \\
\text { (MAN-74) }\end{array}$ & 1955 & 1367 & DSM Energie \\
\hline 33 & $\begin{array}{l}\text { Nijmegen- } \\
\text { Valburg-1 } \\
\text { (NVG-01) }\end{array}$ & 1968 & 1277 & $\begin{array}{l}\text { Zijerveld et al. } \\
\text { (1992) }\end{array}$ \\
\hline 34 & $\begin{array}{l}\text { Reuver-76 } \\
\text { (RVR-76) }\end{array}$ & 1956 & 1105 & DSM Energie \\
\hline 35 & $\begin{array}{l}\text { Rijsbergen-1 } \\
\text { (RSB-01) }\end{array}$ & 1970 & 4645 & NITG-TNO (2001) \\
\hline 36 & $\begin{array}{l}\text { Sanadome-1 } \\
\text { (SNM-499) }\end{array}$ & 1994 & 759 & \\
\hline 37 & $\begin{array}{l}\text { Steelhoven-1 } \\
\text { (STH-01) }\end{array}$ & 1987 & 2798 & NITG-TNO (2001) \\
\hline 38 & $\begin{array}{l}\text { Strijen-1 } \\
\text { (STR-01) }\end{array}$ & 1964 & 2779 & $\begin{array}{l}\text { American Overseas } \\
\text { Petroluem }\end{array}$ \\
\hline 39 & $\begin{array}{l}\text { Vlodrop-1 } \\
\text { (VDP-01) }\end{array}$ & 1906 & 790 & ROvD \\
\hline 40 & $\begin{array}{l}\text { Waspik-1 } \\
\text { (WAP-01) }\end{array}$ & 1959 & 2600 & $\begin{array}{l}\text { Zijerveld et al. } \\
\text { (1992) }\end{array}$ \\
\hline 41 & $\begin{array}{l}\text { Almerk-1 } \\
(\text { ALM-01) }\end{array}$ & 1970 & 2370 & $\begin{array}{l}\text { Zijerveld et al. } \\
\text { (1992) }\end{array}$ \\
\hline
\end{tabular}

\section{References}

Babuska, V., Plomerova, J., Granet, M., 1990. The deep lithosphere in the Alps: a model inferred from $\mathrm{P}$ residuals. Tectonophysics $176,137-165$

Barbarand, J., Carter, A., Pagel, M., 2002. Histoire thermotectonique mésocénozoïque du Massif Central-Conséquence sur la déformation de la lithosphère de l'Europe de l'Ouest. 19ème RST, Nantes, pp. 55-56.

Bergerat, F., 1985. Déformations cassantes et champs de contraintes tertiaires dans la plate-forme européenne. Thesis, P.M. Curie Univ. 315 pp. 
Brun, J.P., Nalpas, T., 1996. Graben inversion in nature and experiments. Tectonics 15, 677-687.

Chlupac, I., Kodym, O., Suk, M., Holub, V., Elias, M., Cicha, I., Malkowsky, M., Tyracek, J., Mencik, E., Buday, T., 1984. Stratigraphic development of the units. In: Suk, M., et al., (Eds.), Geological History of the Territory of the Czech Socialist Republic. Geological survey, Prague, pp. 87-200.

Coulon, M., 1992. La distension oligocène dans le nord-est du bassin de Paris (perturbation des directions d'extension et distribution des stylolites). Bull. Soc. Géol. Fr. 163, 531-540.

de Lugt, I.R., van Wees, J.D., Wong, Th.E., 2003. The tectonic evolution of the southern Dutch North Sea during the Paleogene: a case study for basin inversion in pulses. Tectonophysics.

Demyttenaere, R., Laga, P., 1988. Breuken en isohypsenkaarten van het Belgische gedeelte van de Roerdal Slenk. Belgische Geologische Dienst Professional Paper, 1988/4, 234, 20 pp.

Duchêne, S., Blichert-Toft, J., Luais, B., Telouk, P., Lardeaux, J.M., Albarède, F., 1997. The Lu-Hf dating of garnets and the ages of the alpine high-pressure metamorphism. Nature 387, 586-589.

Elberskirch, W., Wolburg, J., 1962. Zur Tektonik des Karbons am linken Niederrhein im Profil der Bohrungen Wachtendonk 1Emmerich 1. Fortschr. Geol. Rheinld. u. Westf. 6, 407-432.

Fleitout, L., 1984. Modélisation des contraintes tectoniques et des instabilités thermomécaniques dans la lithosphère. Thesis, Orsay University. $433 \mathrm{pp}$.

Geluk, M.C., Duin, E.J., Dusar, M., Rijkers, R.H, van den Berg, M.W., van Rooijen, P., 1994. Stratigraphy and tectonics of the Roer Valley Graben. Geol. Mijnb. 73, 129-141.

Gras, R., Geluk, M., 1999. Late Cretaceous-Early Tertiary sedimentation and tectonic inversion in the southern Netherlands. Geol. Mijnb. 78, 1-19.

Hippolyte, J.C., Angelier, J., Bergerat, F., Nury, D., Guieu, G., 1993. Tectonic-stratigraphic record of paleostress time changes in the Oligocene basins of the Provence, southern France. Tectonophysics $226,15-35$.

Houtgast, R.F., Van Balen, R.T., 2000. Neotectonics of the Roer Valley Rift System, the Netherlands. Global Planet. Change 27, $131-146$.

Hugueney, M., Poidevin, J.L., Bodergat, A.M., Caron, J.B., Guerin, C., 1999. Des mammifères de l'Aquitanien inférieur à La Roche-Banche-Gergovie (Puy-de-Dôme, France), révélateurs de l'activité post-oligocène du rift en Limagne de Clermont. C. R. Acad. Sci. Paris 328, 847-852.

Illies, J.H., 1981. Mechanism of graben formation. Tectonophysics, 249-266.

Krusch, P., Wunstorf, W., 1907. Das Steinkohlengebiet nordostlich der Roer nach den Ergebnisse der Tiefbohrungen und verglichen mit dem Cardiff-District. Glückauf 43, 425-436.

Lake, S.D., Karner, G.D., 1987. The structure and the evolution of the Wessex Basin, southern England: an example of inversion tectonics. Tectonophysics 137, 347-378.

Laubscher, H., 2001. Plate interactions at the southern end of the Rhine graben. Tectonophysics 343, 1-19.

Lefort, J.P., Agarwal, B.N.P., 1996. Gravity evidence for Alpine buckling of the crust beneath the Paris Basin. Tectonophysics 258, $1-14$.

Le Griel, A., 1988. L'évolution géomorphologique du Massif Cen- tral français. Essai sur la genèse d'un relief. Thesis, Lyon II Univ. 569 pp.

Lickorish, W.H., Ford, M., Bürgisser, J., Cobbold, P.R., 2002. Arcuate thrust systems in sandbox experiments: a comparison to the external arcs of the Western Alps. Geol. Soc. Am. Bull. 114, $1089-1107$.

Malkovsky, M., 1987. The Mesozoic and Tertiary basins of the Bohemian Massif and their evolution. Tectonophysics 137, $31-42$.

Meier, L., Eisbacher, G.H., 1991. Crustal kinematics and deep structures of the northern Rhine Graben, Germany. Tectonics $10,621-630$.

Merle, O., Michon, L., 2001. The formation of the West European rift: a new model as exemplified by the Massif Central area. Bull. Soc. Géol. Fr. 172 (2), 213-221.

Merle, O., Michon, L., Camus, G., de Goër, A., 1998. L'extension oligocène sur la transversale septentrionale du rift du Massif Central. Bull. Soc. Géol. Fr. 169, 615-626.

Meyer, W., Albers, H.J., Berners, H.P., Gehlen, K., Glatthaar, D., Lohnertz, W., Pfeffer, K.H., Schnutgen, K., Wienecke, K., Zakosek, H., 1983. Pre-Quaternary uplift in the Central part of the Rhenish Shield. In: Fuchs, K., Von Gelhen, K., Malzer, H., Murawski, H., Semmel, A. (Eds.), Plateau Uplift. The Renish Shield-A Case History. Springer-Verlag, Berlin, pp. 39-46.

Michon, L., 2001. Dynamique de l'extension continentale - application au Rift Ouest Européen par l'étude de la province du Massif Central. Mém. Géosci. Rennes 99, 266 pp.

Michon, L., Merle, O., 2001. The evolution of the Massif Central rift: spatio-temporal distribution of the volcanism. Bull. Soc. Géol. Fr. 172, 201-211.

Monié, P., Philippot, P., 1989. Mise en évidence de l'âge Eocène moyen du métamorphisme de haute-pression dans la nappe ophiolitique du Monviso (Alpes occidentales) par la méthode ${ }^{39} \mathrm{Ar}-{ }^{40}$ Ar. C. R. Acad. Sci. Paris 309, 245-251.

Müller, B., Zoback, M.L., Fuchs, K., Mastin, L., Gregersen, S., et al., 1992. Regional patterns of tectonics stress in Europe. J. Geophys. Res. 97, 11783-11803.

Murawski, H., Albers, H.J., Bender, P., Berners, H.P., Durr, St., Huckriede, R., Kauffmann, G., Kowalczyk, G., Meiburg, P., Muller, R., Ritzkowski, S., Schwab, K., Semmel, A., Stapf, K., Walter, R., Winter, K.P., Zankl, H., 1983. Regional tectonic setting and geological structure of the Rhenish Massif. In: Fuchs, K., von Gelhen, K., Malzer, H., Murawski, H., Semmel, A. (Eds.), Plateau Uplift. The Renish Shield-A Case History. Springer-Verlag, Berlin, pp. 9-38.

Nederlandse Aardolie Maatschappij BV, Rijks Geologische Dienst, 1980. Stratigraphic nomenclature of the Netherlands. Verh. K. Ned. Geol. Mijnbouwkd. Genoot. 32, 77 pp.

NITG-TNO, 2001. Geological Atlas of the Subsurface of the Netherlands: Explanation of map sheet XIII and XIV Breda-Valkenswaard and Oss-Roermond. NITG-TNO, Utrecht. 149 pp.

Oudmayer, B., De Jager, J., 1993. Fault reactivation and obliqueslip in the Southern North Sea. In: Parker, J.R. (Ed.), Petroleum Geology of Northwest Europe. Proceedings of the 4th Conference Geol. Soc., London, pp. 1281-1290.

Peterek, A., Rauche, H., Schroder, B., Franzke, H.-J., Bankwitz, P., Bankwitz, E., 1997. The late- and post-Variscan tectonic evolu- 
tion of the Western Border fault zone of the Bohemian massif (WBZ). Geol. Rundsch. 86, 191-202.

Plenefisch, T., Bonjer, K.P., 1997. The stress field in the Rhine Graben area inferred from earthquake focal mechanisms and estimation of frictional parameters. Tectonophysics 275 , $71-97$.

Racero-Baena, A., Drake, J., 1996. Structural style and reservoir development in the West Netherlands oil province. In: Rondeel, H.E., Batjes, D.A.J., Nieuwenhuijs, W.H. (Eds.), Geology of Gas and Oil Under the Netherlands. Kluwer Academic Publishing, Dordrecht, pp. 211-227.

Rat, P., 1974. Le système Bourgogne-Morvan-Bresse (articulation entre le bassin parisien et le domaine péri-alpin). In: Debelmas, J. (Ed.), Géologie de la France; les chaînes plissées du cycle alpin et leur avant-pays. Doin, Paris, pp. 480-500.

Roure, F., Coletta, B., 1996. Cenozoic inversion structures in the foreland of the Pyrenees and Alps. In: Ziegler, P.A., Horvath, F. (Eds.), Peri-Tethys Memoir 2: Structure and Prospects of Alpine Basins and Forelands. Mém. Mus. Natn. Hist. Nat., vol. 170, pp. 173-209.

Schumacher, M.E., 2002. Upper Rhine Graben: role of preexisting structures during rift evolution. Tectonics 21, 6.1-6.17.

Sclater, J.G., Christie, P.A.F., 1980. Continental stretching: an explanation of post-mid-Cretaceous subsidence of the North Sea Basin. J. Geophys. Res. 85, 3711-3739.

Seranne, M., 1999. The Gulf of Lion continental margin (NW Mediterranean) revisited by IBS: an overview. In: Durand, B., Jolivet, L., Horvath, F., Seranne, M. (Eds.), The Mediterranean Basins: Tertiary Extension within the Alpine Orogen. Geol. Soc. Lond. Spec. Publ., vol. 156, pp. 15-36.

Sissingh, W., 1998. Comparative Tertiary stratigraphy of the Rhine Graben, Bresse Graben and Molasse Basin: correlation of Alpine foreland events. Tectonophysics 300, 249-284

Spicakova, L., Ulicny, D., Koudelkova, G., 2000. Tectonosedimentary evolution of the Cheb basin (NW Bohemia, Czech Republic) between Late Oligocene and Pliocene: a preliminary note. Stud. Geophys. Geod. 44, 556-580.

Tapponnier, P., 1977. Evolution tectonique du système alpin en Mediterranée: poinçonnement et écrasement rigide-plastique. Bull. Soc. Géol. Fr. 19, 437-460.

Tilton, G.R., Schreyer, W., Schertl, H.P., 1991. Pb-Sr-Nd isotopic behavior of deeply subducted crustal rocks from the Dora Maira Massif, Western Alps, Italy: II. What is the age of the ultrahigh-pressure metamorphism? Contrib. Mineral. Petrol. 108, 22-33.

Tricart, P., Schwartz, S., Sue, C., Poupeau, G., Lardeaux, J.M., 2001. La dénudation tectonique de la zone ultradauphinoise et l'inversion du front briançonnais au sud-est du Pelvoux (Alpes occidentales): une dynamique miocène à actuelle. Bull. Soc. Géol. Fr. 172, 49-58.

Van Balen, R.T., Podladchikov, Y.Y., Cloetingh, S.A.P.L., 1998. A new multilayered model for intraplate stress-induced differential subsidence of faulted lithosphere, applied to rifted basins. Tectonics $17,938-954$.

Van Balen, R.T., Van Bergen, F., de Leeuw, C., Pagnier, H., Simmelink, H., Van Wees, J.D., Verweij, J.M., 2000. Modelling the hydrocarbon generation and migration in the West Netherlands Basin, the Netherlands. Geol. Mijnb., Neth. J. Geosci. 79, 29-44.

Van Balen, R.T., Verweij, J.M., Van Wees, J.D., Simmelink, H., Van Bergen, F., Pagnier, H., 2002. Deep subsurface temperatures in the Roer Valley Graben and the Peel Block, the Netherlandsnew results. Neth. J. Geosci., Geol. Mijnb. 81, 19-26.

Van Hinte, J.E., 1978. Geohistory analysis-application of micropaleontology. Am. Assoc. Pet. Geol. Bull. 62, 201-222.

Verbeek, J.W., de Leeuw, C.S., Parker, N., Wong, Th.E., 2002. Characterisation and correlation of Tertiary seismostratigraphic units in the Roer Valley Graben. Geol. Mijnb., Neth. J. Geosci. $81,159-166$.

Villemin, T., Bergerat, F., 1987. L'évolution structurale du fosse rhenan au cours du Cénozoïque: un bilan de la déformation et des effets thermiques de l'extension. Bull. Soc. Géol. Fr. 3, $245-255$.

Von Blanckenburg, F., Davies, J.H., 1995. Slab breakoff: a model for syncollisional magmatism and tectonics in the Alps. Tectonics $14,120-131$.

Winstanley, A.M., 1993. A review of the Triassic play in the Roer Valley Graben, SE onshore Netherlands. In: Parker, J.R. (Ed.), Petroleum Geology of Northwest Europe. Proceedings of the 4th Conference Geol. Soc., London, pp. 595-607.

Zagwijn, W.H., 1989. The Netherlands during the Tertiary and the Quaternary: a case history of coastal lowland evolution. Geol. Mijnb. 68, 107-120.

Ziegler, P.A., 1988. Evolution of the Artic North Atlantic and the western Tethys. Am. Assoc. Pet. Geol. Mem. 43, 198 pp.

Ziegler, P.A., 1990. Geological atlas of western and central Europe, 2nd ed. Shell Internationale Petroleum Mij., distributed by Geol. Soc., London, Publ. House, Bath. 238 pp., 56 encl.

Ziegler, P.A., 1992a. North Sea rift system. In: Ziegler, P.A. (Ed.), Geodynamics of Rifting, Volume I. Case History Studies on Rifts: Europe and Asia. Tectonophysics, vol. 208, pp. 55-75.

Ziegler, P.A., 1992b. European Cenozoic rift system. In: Ziegler, P.A. (Ed.), Geodynamics of Rifting, Volume I. Case History Studies on Rifts: Europe and Asia. Tectonophysics, vol. 208, pp. 91-111.

Ziegler, P.A., Roure, F., 1996. Architecture and petroleum systems of the Alpine orogen and associated basins. In: Ziegler, P.A., Horvath, F. (Eds.), Peri-Tethys Memoir 2: Structure and Prospects of Alpine Basins and Forelands. Mém. Mus. Natn. Hist. Nat., vol. 170, pp. 15-45.

Zijerveld, L., Stephenson, R., Cloetingh, S., Duin, E., Van den Berg, M.W., 1992. Subsidence analysis and modelling of the Roer Valley Graben (SE Netherland). Tectonophysics 208, $159-171$. 